\title{
Inhibition of Calcium Channels in Rat CA3 Pyramidal Neurons by a Metabotropic Glutamate Receptor
}

\author{
Kenton J. Swartz and Bruce P. Bean \\ Department of Neurobiology, Harvard Medical School, Boston, Massachusetts 02115
}

L-Glutamate rapidly and reversibly suppressed Ca channel current in freshly dissociated pyramidal neurons from the CA3 region of the rat hippocampus. L-Glutamate inhibition of $\mathrm{Ca}$ channel current could be distinguished from activation of background conductance by appropriate ionic conditions and by distinct pharmacological profiles. Ca channel inhibition by glutamate was mimicked by quisqualate, ibotenate, racemict-ACPD and 1 S,3R-ACPD but not by kainate, AMPA, L-aspartate, NMDA, L-2-amino-4-phosphonobutyric acid, or 1R,3S-ACPD; 6-cyano-7-nitroquinoxaline-2,3-dione did not inhibit the response. All agonists inhibited a similar fraction of high-voltage-activated Ca channel current, typically $\sim 30 \%$. Concentration-response relations for the agonists were consistent with mediation by a metabotropic glutamate receptor. The stereospecific agonist 1 S,3R-ACPD was especially useful since it did not activate background conductances. The fraction of $\mathrm{Ca}$ channel current sensitive to 1 S,3R-ACPD was partially blocked by $\omega$-conotoxin GVIA but was not sensitive to dihydropyridine antagonists or agonists. The suppression of Ca channels by $1 S, 3 R$-ACPD became irreversible when cells were dialyzed with GTP- $\gamma$-S. 1S,3R-ACPD suppressed Ca channel currents in outside-out membrane patches but not in cell-attached patches when applied outside the patch. These results suggest that metabotropic glutamate receptors suppress the activity of $\mathrm{N}$-type $\mathrm{Ca}$ channels in $\mathrm{CA} 3$ neurons by a mechanism involving $\mathrm{G}$-proteins but not readily diffusible second messengers.

A number of examples are known in which neurotransmitters can inhibit their own release by acting on presynaptic autoreceptors (Koelle, 1961; Illes, 1986; North, 1986; Starke, 1987; Lipscombe et al., 1989; Kalsner and Westfall, 1990). One mechanism mediating such presynaptic inhibition is likely to be neurotransmitter inhibition of $\mathrm{Ca}$ channels in the presynaptic terminal. Virtually all neurotransmitter receptors known to be couplcd to $G_{i}$ or $G_{0}$-like $G$-proteins have been shown to inhibit Ca channels in one cell type or another (Carbone and Swandulla, 1991; Anwyl, 1991). In vertebrate neurons, suppression of Ca currents has been studied primarily in cell bodies, but the mechanism has also been demonstrated in presynaptic terminals (Maguire et al., 1989). Other mechanisms might also be involved

\footnotetext{
Received Apr. 9, 1992; revised May 21, 1992; accepted June 2, 1992.

We thank Linda Boland, James Huettner, Isabelle Mintz, and James Morrill for helpful discussions. This work was supported by grants from the National Institutes of Health (HL 35034 and NS 02253). K.J.S. was supported by a fellowship from the Mahoney Institute.

Correspondence should be addressed to Kenton J. Swartz, Department of Neurobiology, Harvard Medical School, Building B2, 220 Longwood Avenue, Boston, MA 02115.

Copyright (C) 1992 Society for Neuroscience $0270-6474 / 92 / 124358-14 \$ 05.00 / 0$
}

in presynaptic suppression of transmitter release since many of the same transmitters also activate potassium channels (Illes, 1986; North, 1986).

L-Glutamate is probably the predominant fast excitatory neurotransmitter in the mammalian brain (Mayer and Westbrook, 1987; Dingledine et al., 1988). Recently, two groups reported that stimulation of glutamate receptors can inhibit $\mathrm{Ca}$ channels in hippocampal neurons (Lester and Jahr, 1990; Chernevskaya et al., 1991). In one study on cultured hippocampal neurons, the suppression of Ca current could be produced by L-glutamate and quisqualate, but not $R S$ - $\alpha$-amino-3-hydroxy-5-methyl-4isoxazolepropionic acid (AMPA), $N$-methyl-D-aspartate (NMDA), or L-2-amino-4-phosphonobutyric acid (L-AP4) (Lester and Jahr, 1990). Suppression was readily detected only if GTP- $\gamma-\mathrm{S}$ was present in the patch pipette, and was slow, taking about $40 \mathrm{sec}$ to reach completion. In this study, suppression of $\mathrm{Ca}$ channel current had a requirement for external or internal $\mathrm{Ca}$ (Lester and Jahr, 1990). In contrast, another study on freshly dissociated hippocampal neurons (Chernevskaya et al., 1991) found that the suppression of Ca current by glutamate was mimicked by NMDA receptor agonists and could be blocked by NMDA receptor antagonists. The onset of suppression by NMDA receptor agonists required minutes to develop fully and was irreversible.

We have further studied glutamate inhibition of Ca channels in hippocampal neurons, using freshly dissociated pyramidal neurons from the CA3 region of the rat hippocampus. We found rapid $\left(t_{\mathrm{on}} \sim 2 \mathrm{sec}\right)$ and reversible inhibition of Ca channel current with no apparent requirement for $\mathrm{Ca}$ or involvement of internal Ca stores. In agreement with Lester and Jahr (1990), the effect of glutamate was mimicked by quisqualate but not by NMDA, AMPA, or kainate. In addition to glutamate and quisqualate, ibotenate, \pm -1-aminocyclopentane-trans-1,3-dicarboxylic acid (racemic $t$-ACPD), and $1 S, 3 R-1$-aminocyclopentane-1,3-dicarboxylic acid ( $1 S, 3 R$-ACPD) inhibited Ca channel current; agonist affinitics wcre consistcnt with mediation by a metabotropic glutamate receptor. Inhibition was selective for $\mathrm{N}$-type over L-type Ca channels. Metabotropic glutamate receptors were found to be coupled to Ca channels by a pathway involving G-proteins but not a readily diffusible second messenger.

\section{Materials and Methods}

Cell preparation. Pyramidal neurons were dissociated from the CA3 region of hippocampal slices $(400 \mu \mathrm{m})$ obtained from 7-21-d-old LongEvans rats using solutions modified from those of Furshpan and Potter (1989). Slices were incubated at $37^{\circ} \mathrm{C}$ for $8-10 \mathrm{~min}$, in an $\mathrm{O}_{2}$ atmosphere, in a solution containing $3 \mathrm{mg} / \mathrm{ml}$ protease XXIII (Sigma, St. Louis, MO) (see Kiskin et al., 1990), $82 \mathrm{mM} \mathrm{Na}_{2} \mathrm{SO}_{4}, 30 \mathrm{mM} \mathrm{K}_{2} \mathrm{SO}_{4}, 5 \mathrm{mM} \mathrm{MgCl}$, 2 mM $N$-[2-hydroxyethyl]piperazine- $N^{\prime}$-[2-ethanesulfonicacid] (HEPES), $10 \mathrm{mM}$ glucose, and $0.001 \%$ phenyl red indicator, $\mathrm{pH} 7.4$. Slices were transferred to a solution containing $1 \mathrm{mg} / \mathrm{ml}$ bovine serum albumin (Sigma), $1 \mathrm{mg} / \mathrm{ml}$ trypsin inhibitor (Sigma), $82 \mathrm{mM} \mathrm{Na}_{2} \mathrm{SO}_{4}, 30 \mathrm{mM}$ 
$\mathrm{K}_{2} \mathrm{SO}_{4}, 5 \mathrm{mM} \mathrm{MgCl}, 10 \mathrm{mM}$ HEPES, $10 \mathrm{mM}$ glucose, and $0.001 \%$ phenyl red indicator, $\mathrm{pH} 7.4$, and allowed to cool to room temperature in an $\mathrm{O}_{2}$ atmosphere. As cells were needed, slices were withdrawn and the $\mathrm{CA} 3$ region dissected and triturated to release individual cells. Cells were placed in the recording chamber in a Tyrode's solution containing (in $\mathrm{mM}$ ) $150 \mathrm{NaCl}, 4 \mathrm{KCl}, 2 \mathrm{CaCl}_{2}, 2 \mathrm{MgCl}_{2}, 10$ glucose, and $10 \mathrm{HEPES}$, $\mathrm{pH}$ 7.4. Cells were typically used within $4 \mathrm{hr}$ of the preparation of slices.

Whole-cell recordings. Whole-cell voltage-clamp recordings (Hamill et al., 1981) were obtained using pipettes pulled from $100 \mu \mathrm{l}$ Boralex micropipettes (Dynalab, Rochester, NY) coated with Sylgard and fire polished. Pipette resistances ranged from 2 to $6 \mathrm{M} \Omega$ when filled with the internal solution consisting of (in $\mathrm{mM}$ ) 117 tetraethylammonium (TEA) chloride, $4.5 \mathrm{MgCl}_{2}, 9$ HEPES, 9 ethyleneglycol-bis-( $\beta$-aminoethylether)- $N, N, N^{\prime}, N^{\prime}$-tetraacetic acid (EGTA), 14 creatine phosphateTris (Sigma), 4 adenosine $5^{\prime}$-triphosphate magnesium salt (Mg-ATP) (Sigma), and 0.3 guanosine 5'-triphosphate Tris salt (GTP-Tris) (Sigma), pH adjusted to 7.4 with TEAOH. Creatine phosphate, ATP, and GTP were stored as aliquots at $-70^{\circ} \mathrm{C}$, and the solution was kept on ice after they were added. The external recording solution contained (in $\mathrm{mM}$ ) $25 \mathrm{BaCl}_{2}, 145$ TEACl, $10 \mathrm{HEPES}$, and 0.1 EGTA, pH 7.4 with TEAOH. Drug solutions were applied by gravity-driven perfusion from a linear array of 12 microcapillary tubes (Drummond Microcaps; $2 \mu \mathrm{l}, 64 \mathrm{~mm}$ length). Solution was exchanged in $<250 \mathrm{msec}$ (cf. Friel and Bean, 1988) as confirmed by block of $\mathrm{Ba}$ currents by $\mathrm{CdCl}_{2}$ or the change in holding potential produced by $100 \mu \mathrm{M}$ kainate. Seals were formed and the wholecell configuration obtained in Tyrode's solution before perfusing the cell with the external solution containing TEA and $\mathrm{Ba}$. Whole-cell currents recorded with a List EPC-7 patch amplifier were filtered at either $2 \mathrm{KHz}$ (8-pole Bessel low-pass) or $3 \mathrm{KHz}$ (4-pole Bessel low-pass), digitized, and stored using a BASIC-FASTLAB analog/digital interface and software (Indec Systems, Sunnyvale, CA).

Outside-out patch recordings. Pipettes had resistances ranging from 4 to $10 \mathrm{M} \Omega$ when filled with the same internal solution that was used for whole-cell recording. The external recording solution contained (in mM) $110 \mathrm{BaCl}_{2}, 10 \mathrm{HEPES}$, and 0.1 EGTA, $\mathrm{pH} 7.4$ with $\mathrm{BaOH}_{2}$. Drugs were applied as described for whole-cell recording. Cells were fixed to the bottom of the recording chamber by first coating it with polylysine and laminin.

Cell-attached patch recordings. Pipettes had resistances ranging from 10 to $20 \mathrm{M} \Omega$ when filled with a solution containing (in $\mathrm{mM}$ ) $110 \mathrm{BaCl}_{2}$, $20 \mathrm{TEACl}, 10 \mathrm{HEPES}$, and 0.1 EGTA, pH 7.4 with $\mathrm{BaOH}_{2}$. Seals were formed in the bath Tyrode's solution before perfusing the cell with a high-K solution to zero the cell membrane potential. The zeroing solution contained (in $\mathrm{mM}$ ) $145 \mathrm{~K}$-gluconate, $10 \mathrm{HEPES}, 5 \mathrm{MgCl}_{2}$, and 1 EGTA, pH 7.4 with $\mathrm{KOH}$.

Leak subtraction. In early experiments with $C_{s}$ as the main internal cation, we discovered that agonist-gated currents through glutamate receptor channels could interfere with measurements of $\mathrm{Ca}$ channel currents. For example, kainate acting on non-NMDA receptor channels can produce an apparent reduction of inward $\mathrm{Ca}$ channel current near $0 \mathrm{mV}$ by activating outward current carried by Cs. In order to suppress currents gated by excitatory amino acids, TEA was therefore used as the main cation in both internal and external solutions. Under these conditions, the leak conductance (determined after block of Ca channels by $C d$ ) was small and reversed near $0 \mathrm{mV}$ (Fig. $1 A$ ). Often the leak conductance was non-ohmic, with a concave downward shape negative to $0 \mathrm{mV}$. In such cells, it would be inappropriate to use standard leak correction by linear scaling of currents elicited near the holding potential since linear extrapolation would incorrectly predict large outward leak currents near $0 \mathrm{mV}$ (Fig. $1 A$ ). Since leak currents were always small even at $-80 \mathrm{mV}$ and were much smaller near $0 \mathrm{mV}$, where we measured Ca channel currents, it was more accurate to make measurements of test current on raw currents. Figures $1-6$ and 10-12 show raw, uncorrected currents; capacity transients were reduced by the electronic compensation circuit in the patch-clamp amplifier. When tail currents were measured, leak and capacitative currents were subtracted using linearly scaled currents elicited by a step from -80 to $-90 \mathrm{mV}$; these experiments were confined to cells (e.g., Figs. 8,9 ) in which the leak current was nearly linear and current at $-10 \mathrm{mV}$ was little affected by subtraction. Leak current in outside-out and cell-attached patches was generally linear and was subtracted, along with capacity transients, by extrapolation from negative potentials (see Figs. 13, 14).

All statistical results are given as mean \pm SEM.

Agonist-gated conductances. Using the internal and external solutions with TEA as the main cation, glutamate-activated current was greatly
A
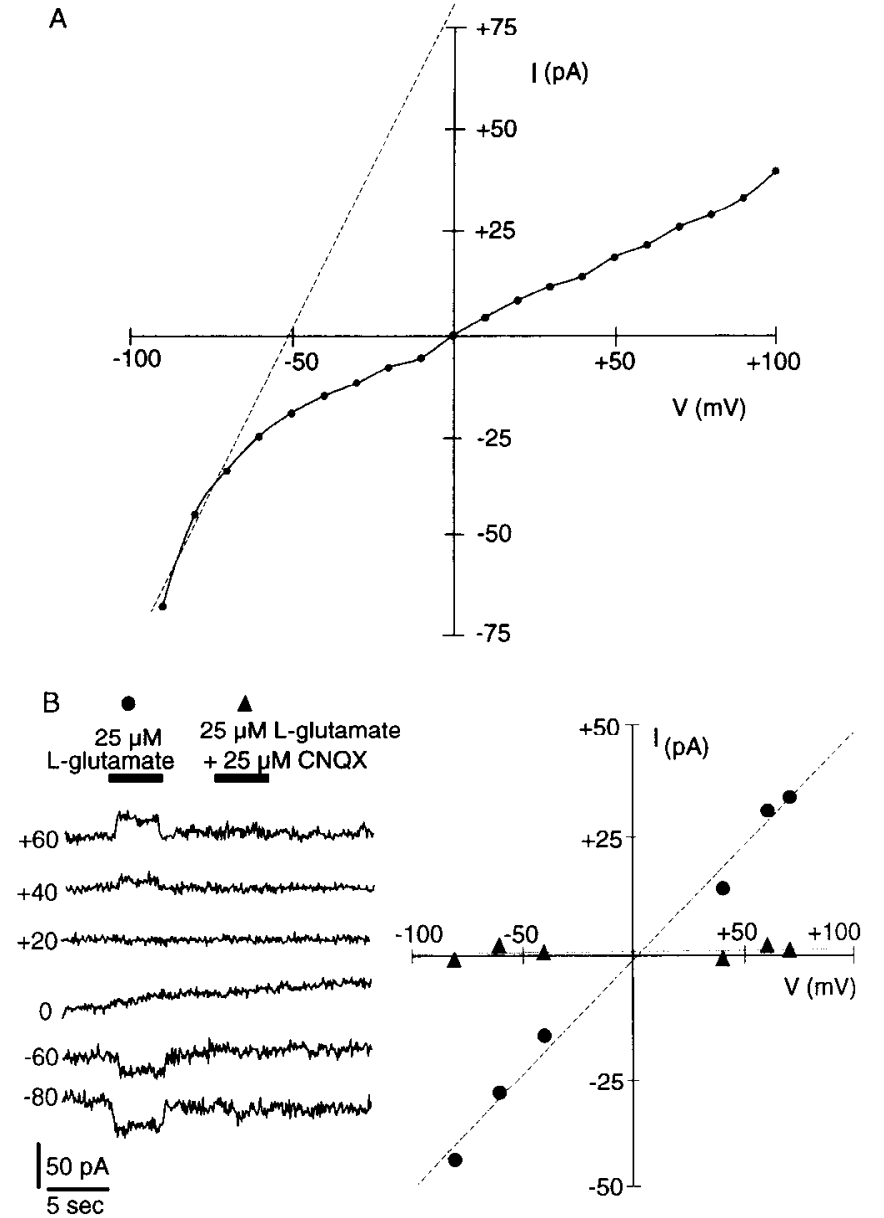

Figure 1. Current-voltage relationships for leak and L-glutamate-activated conductances. $A$, Current-voltage relations for leak current after block of Ca channels by $2 \mathrm{mM} \mathrm{CdCl}$. $B$, Current-voltage relation for currents activated by $25 \mu \mathrm{M}$ L-glutamate alone (circles) and with $25 \mu \mathrm{M}$ CNQX (triangles). Glutamate was applied for $5 \mathrm{sec}$ while the cell was held steadily at a given potential. The straight line in the right panel (intercepting the $\mathrm{x}$-axis at $+4 \mathrm{mV}$ ) was fit by linear regression.

reduced (compared with $\mathrm{Na}$ outside and $\mathrm{K}$ or $\mathrm{Cs}$ inside), but not completely eliminated. Figure $1 B$ shows an experiment in which we determined the current-voltage relationship for glutamate-activated current under the standard ionic conditions we used in these studies. The glutamate-activated current reversed near $0 \mathrm{mV}(+4 \mathrm{mV}$ in this cell). Presumably, the inward current is carried mainly by $\mathrm{Ba}$ ions and outward current mainly by $\mathrm{Mg}$ ions (with a small permeability of TEA also possible). In the absence of glycine, cation channels gated by L-glutamate are predominantly of the non-NMDA (AMPA/kainate) receptor type (Johnson and Ascher, 1987; Kleckner and Dingledine, 1988). 6-Cyano7-nitroquinoxaline-2,3-dione (CNQX) is a relatively selective antagonist of non-NMDA receptor channels in vertebrate neurons (Honore et al., 1988; Verdoorn et al., 1989). We tested what concentration of CNQX was necded to inhibit the glutamate-activated current with these ionic conditions, since this is a crucial tool for distinguishing glutamate-activated current from glutamate modulation of Ca channels. Concentration-response relations were first obtained for CNQX against current activated by $25 \mu \mathrm{M}$ L-glutamate or $100 \mu \mathrm{M}$ kainate in a series of eight cells dialyzed with an internal solution in which $108 \mathrm{mM} \mathrm{CsCl}$ replaced $108 \mathrm{mM} \mathrm{TEACl}$; internal Cs resulted in large outward currents activated by glutamate or kainate at potentials ranging from -30 to $+30 \mathrm{mV}$, facilitating accurate measurements of CNQX block of L-glutamate- or kainate-gated conductances. Half-maximal inhibition of either L-glutamate- or kainate-gated conductances were obtained with $\sim 1 \mu \mathrm{M}$ CNQX; $5 \mu \mathrm{M}$ CNQX produced $\sim 90 \%$ block, and $25 \mu \mathrm{M}$ CNQX provided complete block. In 10 other pyramidal neurons dialyzed with the 

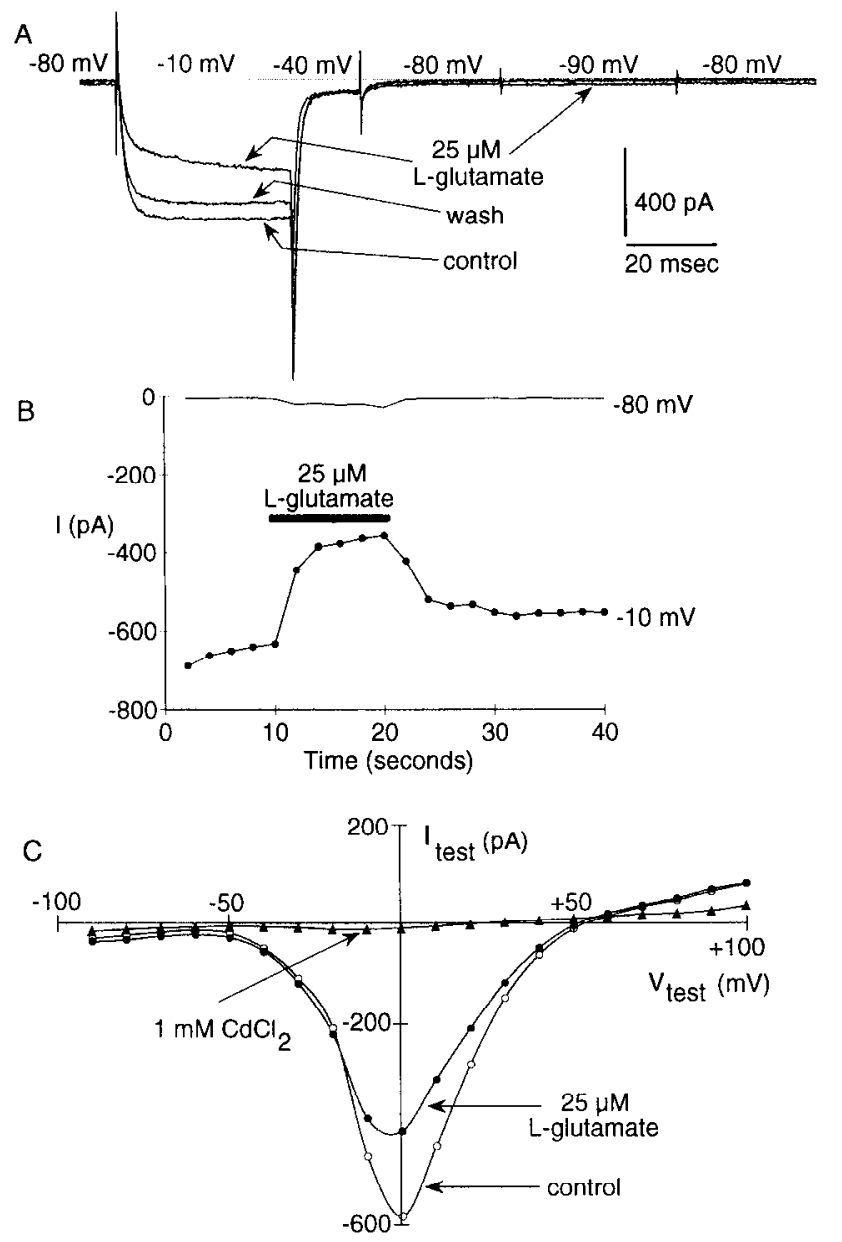

Figure 2. L-Glutamate inhibition of Ca channel current. $A$, Wholecell currents recorded in control, $4 \mathrm{sec}$ after application of $25 \mu \mathrm{M} \mathrm{L-glu-}$ tamate, and $10 \mathrm{sec}$ after removal of L-glutamate. The broken line is drawn at 0 current. $B$. Time course of Ca channel inhibition by $25 \mu \mathrm{M}$ L-glutamate; same cell as in $A$. The pulse pattern shown in $A$ was repeated every $2 \mathrm{sec}$. Holding current was measured at $-80 \mathrm{mV}$. Ca channel current was measured $10 \mathrm{msec}$ after stepping to $-10 \mathrm{mV}$ (circles). $C$, Current-voltage relationship of depolarization-activated current in the absence (solid circles) and presence (open circles) of $25 \mu \mathrm{M}$ L-glutamate and after blocking Ca channels with $1 \mathrm{mM} \mathrm{CdCl}$ (solid triangles). Holding potential, $-80 \mathrm{mV}$.

standard internal solution containing $108 \mathrm{mM} \mathrm{TEACl}$, we confirmed that $25 \mu \mathrm{M}$ CNQX completely blocked currents activated by $25 \mu \mathrm{M}$ L-glutamate at potentials ranging from -80 to $+80 \mathrm{mV}$ (see Figs. $1 B$, 4).

Concentration-response experiments. Concentration-response relations for agonists were obtained by applying a set of five to seven different agonist concentrations. In most experiments, each concentration was applied for $\sim 10 \mathrm{sec}$; the full set of applications was usually repeated more than once in the same cell with similar or identical results. Saturating concentrations normally bracketed each full set of agonist applications to control for change in response with time. The suppression of $\mathrm{Ba}$ current by a concentration of agonist was measured as the percentage inhibition of Ba current, normalized by the inhibition produced in the same cell by a saturating concentration of the agonist.

Compounds. L-Glutamate, L-aspartate, kainate, $N$-methyl-D. aspartate, ibotenate, glycine, \pm -baclofen, 2-chloroadenosine (2-Cl-adenosine), guanosine-5'-triphosphate (GTP), and guanosine-5'-O-(3thiophosphate) (GTP- $\gamma-S)$ were obtained from Sigma. Synthetic $(+)$-quisqualate was obtained from Research Biochemicals Inc. (Waltham, MA). 6-Cyano-7-nitroquinoxaline-2,3-dione (CNQX), $R S$ - $\alpha$ amino-3-hydroxy-5-methyl-4-isoxazolepropionic acid (AMPA), \pm-1 aminocyclopentane-trans-1,3-dicarboxylic acid (racemic $t$-ACPD), $1 S, 3 R$-1-aminocyclopentane-1,3-dicarboxylic acid ( $1 S, 3 R$-ACPD),
$1 R, 3 S$-1-aminocyclopentane-1,3-dicarboxylic acid (1R,3S-ACPD), L-2amino-4-phosphonobutyric acid (L-AP4), and L-2-amino-3-phosphonopropionic acid (L-AP3) were obtained from Tocris Neuramine (Bristol, UK). Another batch of L-AP3 was the kind gift of Dr. D. Schoepp (Lilly Research Laboratories, Indianapolis, IN). Nimodipine was a generous gift of Dr. Alexander Scriabine (Miles Laboratories, West Haven, CT) (+)-S-202-791 was a gift of Dr. R. P. Hof (Sandoz, Basel, Switzerland). Synthetic $\omega$-conotoxin GVIA ( $\omega$-CgTx-GVIA) and somatostatin were obtained from Peninsula Laboratories (Belmont, CA).

\section{Results}

\section{Glutamate inhibition of Ba currents}

Whole-cell currents were recorded using $\mathrm{Ba}$ as the charge carrier and TEA as the predominant internal and external cation. Under these ionic conditions, L-glutamate-gated conductances were greatly reduced, and modulation of $\mathrm{Ca}$ channel current could be clearly distinguished from activation of background current. Figure 2 illustrates the effect of $25 \mu \mathrm{M} \mathrm{L}$-glutamate on Ba current in hippocampal pyramidal neurons. In the experiment illustrated in Figure 2, $A$ and $B$, Ba current was evoked every $2 \mathrm{sec}$ by a $50 \mathrm{msec}$ voltage step from -80 to $-10 \mathrm{mV}$. Application of $25 \mu \mathrm{M} \mathrm{L}$-glutamate resulted in a rapid inhibition of Ba current that reached steady-state in $4 \mathrm{sec}$ (Fig. $2 \mathrm{~B}$ ); in this cell, $25 \mu \mathrm{M}$ L-glutamate caused a $40 \%$ reduction in the inward current measured $10 \mathrm{msec}$ after the step to $-10 \mathrm{mV}$, when control Ba current was maximal. In 22 cells tested with the protocol in Figure 2, $A$ and $B, 25 \mu \mathrm{M}$ L-glutamate caused a mean reduction in $\mathrm{Ba}$ current of $26 \pm 2 \%$ (range, $15-45 \%$ ). In addition to depressing the Ba current, L-glutamate induced a slow phase of activation not present in control, an effect previously seen with other transmitters that inhibit $\mathrm{Ca}$ channels (e.g., Forscher and Oxford, 1985; Marchetti et al., 1986; Ikeda and Schofield, 1989; Kasai and Aosaki, 1989). The effect of L-glutamate rapidly reversed on return to control solution, with significant reversal within 2 sec and steady-state achieved in $8 \mathrm{sec}$ (Fig. $2 \mathrm{~B}$ ). In most cells, reversal was complete (Figs. 3-6); when it was not (e.g., Fig. $2 B$ ), the decline in current sccmcd consistent with "rundown" seen under control conditions.

In some cells (including that in Fig. $2 A, B$ ), L-glutamate produced a small increase in the holding current at $-80 \mathrm{mV}$ due to activation of glutamate receptor channels, presumably passing small currents carried by $\mathrm{Ba}$ and possibly TEA. Since this current reverses slightly positive to $0 \mathrm{mV}$ (Fig. $1 B$ ), activation of these channels would produce an enhanced inward current at $-10 \mathrm{mV}$, so this clearly cannot account for the reduction in inward Ca channel current at $-10 \mathrm{mV}$ caused by L-glutamate. In principle, the current induced by conventional glutamate receptors could partly counteract the reduction in inward $\mathrm{Ca}$ channel current at $-10 \mathrm{mV}$ caused by L-glutamate, but with these ionic conditions the effect would be very small. For example, in the cell shown in Figure 2, $A$ and $B$, the inward current induced at $-80 \mathrm{mV}$ is $-15 \mathrm{pA}$, and since L-glutamate-activated currents have a roughly linear current-voltage rclation, reversing near $+5 \mathrm{mV}$ (Fig. 1), the inward current induced at -10 $\mathrm{mV}$ would be about $-3 \mathrm{pA}$, negligible compared to the control current of $-640 \mathrm{pA}$ or to the reduction of $280 \mathrm{pA}$ caused by L-glutamate. Also, although L-glutamate reduced the inward $\mathrm{Ca}$ channel current elicited by stepping to $-10 \mathrm{mV}$ in every neuron tested, in many neurons effects on holding current were too small to be detectable even at $-80 \mathrm{mV}$ (e.g., Fig. 3).

Figure $2 C$ illustrates the current-voltage relation for a neuron in the absence and presence of $25 \mu \mathrm{M}$ L-glutamate. As expected for an effect on $\mathrm{Ca}$ channels, the changes in $\mathrm{Ba}$ current produced by L-glutamate were largest at the voltages (near $0 \mathrm{mV}$ ) where 

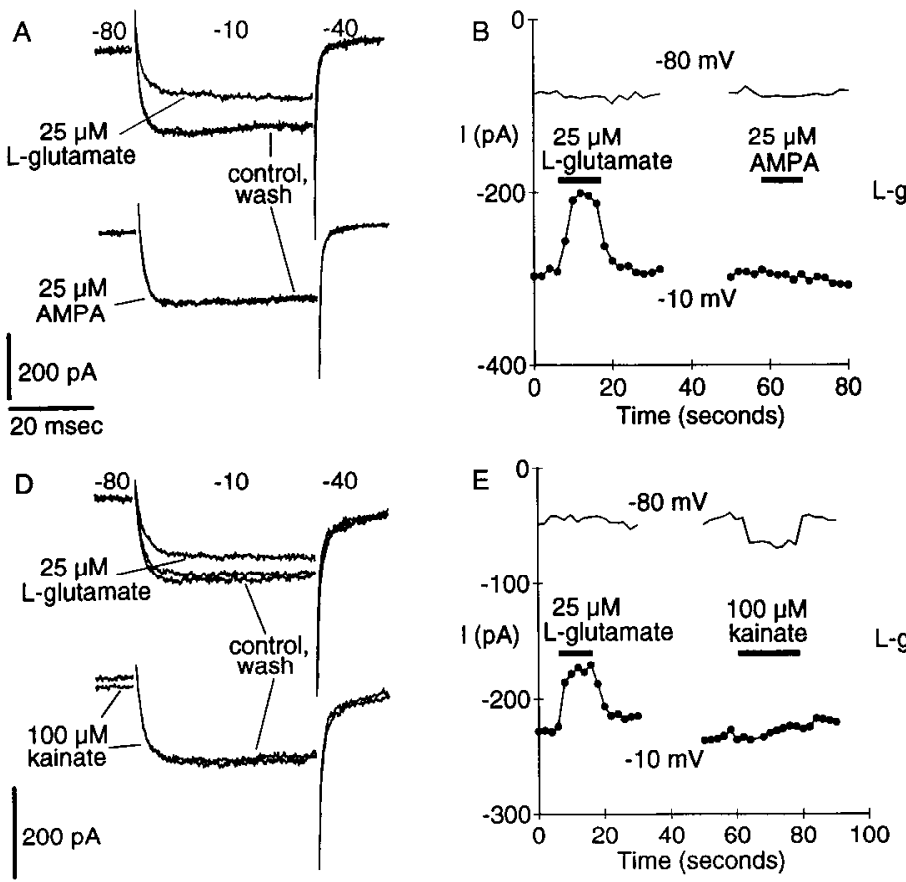

the Ca channel current was most pronounced and the current gated by L-glutamate is smallest (Fig. $1 B$ ).

We conclude that the reduction in inward current elicited by depolarization represents modulation of Ca channel current, and is not an artifact due to activation of current through glutamategated channels.

\section{Receptor pharmacology}

Figure 3 compares the effect of L-glutamate with that of kainate and AMPA, agonists at non-NMDA glutamate receptors (O'Brien and Fischbach, 1986; Verdoorn and Dingledine, 1988; Zorumski and Yang, 1988; Patneau and Mayer, 1990, 1991). Neither AMPA nor kainate had a significant effect on Ca channel current, even when tested in cells with reproducible responses to L-glutamate (Fig. 3). The effects of kainate offered an especially clear distinction between activation of current through non-NMDA receptor channels and the modulation of $\mathrm{Ca}$ channel current; kainate induced a substantial inward current at $-80 \mathrm{mV}$ (Fig. $3 D, C$ ) but had no effect on the Ca channel current at $-10 \mathrm{mV}$. [The larger effects of kainate, when compared to L-glutamate or AMPA, on background current are expected, since kainate activates currents with much larger steady-state components than L-glutamate or AMPA, both of which induce rapidly desensitizing currents (Kiskin et al., 1986; Patneau and Mayer, 1990, 1991).]

CNQX, an antagonist at non-NMDA receptors (Honore et al., 1988; Verdoorn et al., 1989), had no effect on the ability of L-glutamate to depress Ca channel current (Fig. 4), even when present at $25 \mu \mathrm{M}$, a concentration that completely inhibited L-glutamate activation of background current in the same cell (Fig. 4; see also Fig. $1 B$ and Materials and Methods).

These results, summarized in Figures $3, C$ and $F$, and $4 B$, show that the reduction in Ca channel current by L-glutamate is mediated by a receptor with pharmacological sensitivities different than non-NMDA (kainate/AMPA) receptors.

NMDA receptors also do not mediate the effects of L-glutamate on Ca channel current. L-Aspartate, an agonist at NMDA receptors, had no effect on $\mathrm{Ca}$ channel current (Fig. 5A-C). NMDA $(100 \mu \mathrm{M})$ also had no effect on Ca channel current (Fig.
C

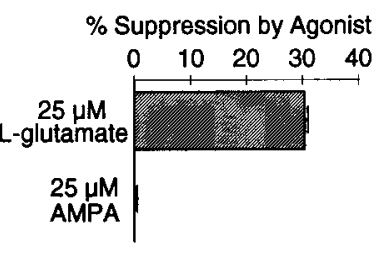

Figure 3. Lack of effect of AMPAkainate receptor agonists. $A$, Inhibition of whole-cell Ba current by $25 \mu \mathrm{M}$ L-glutamate but not $25 \mu \mathrm{M}$ AMPA. $B$, Effects of L-glutamate and AMPA on steady current at $-80 \mathrm{mV}$ and on current elicited by a step to $-10 \mathrm{mV}$; same neuron as in $A$. Pulses from -80 to -10 $\mathrm{mV}$ were elicited every $2 \mathrm{sec} . C$, Pooled results in four cells. L-Glutamate at 25 $\mu \mathrm{M}$ was applied to every cell before and after testing the effects of AMPA. $D$ and $E$, Inhibition of Ba current by $25 \mu \mathrm{M}$ L-glutamate but not $100 \mu \mathrm{M}$ kainate. Pulses from -80 to $-10 \mathrm{mV}$ were elicited every $2 \mathrm{sec} . F$, Collected results in four cells. L-Glutamate at $25 \mu \mathrm{M}$ was applied to every cell before and after testing the effects of kainate. All currents were elicited by steps to -10 or $0 \mathrm{mV}$ from $-80 \mathrm{mV}$.
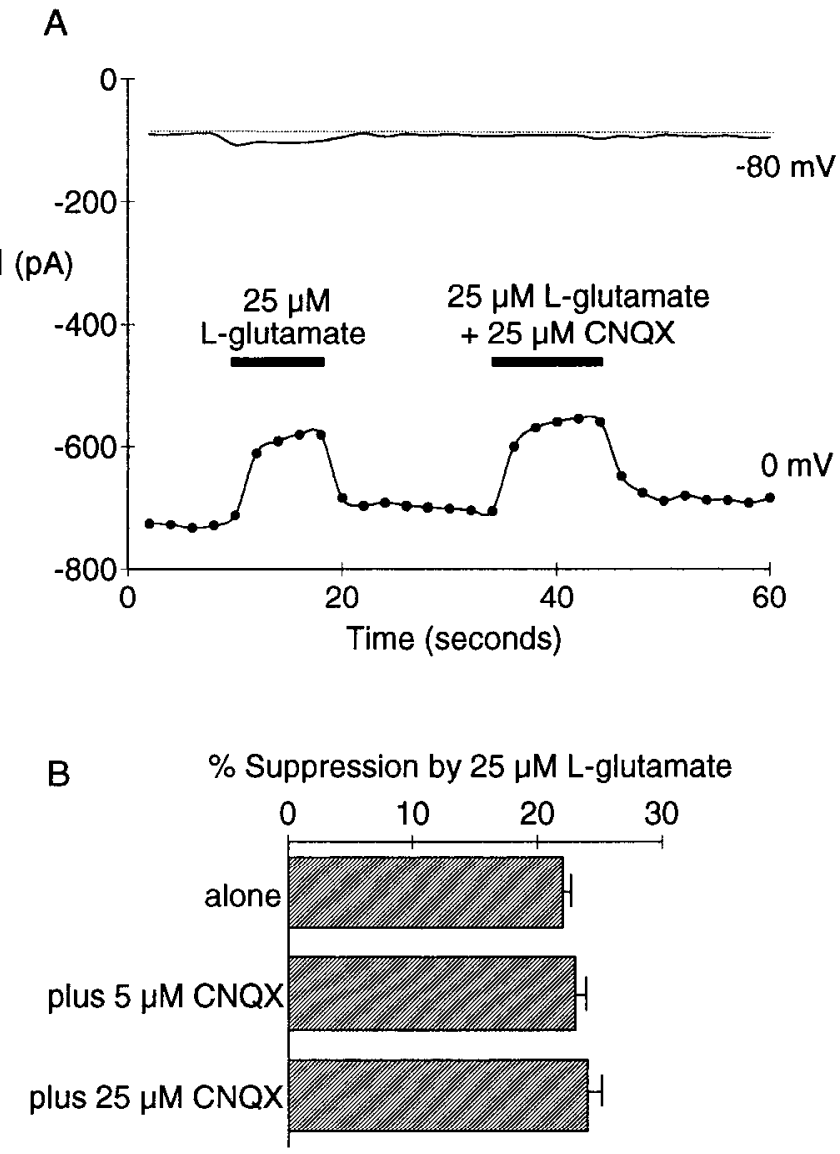

Figure 4. Lack of effect of CNQX on L-glutamate suppression of Ca channels. $A$, Action of $25 \mu \mathrm{M}$ L-glutamate on whole-cell Ba current in the absence or presence of $25 \mu \mathrm{M}$ CNQX. Glutamate produced a small increase in holding current at $-80 \mathrm{mV}$, which was blocked by CNQX. Pulses from -80 to $0 \mathrm{mV}$ were applied every $2 \mathrm{sec} . B$, Collected results; CNQX was tested in eight cells at $5 \mu \mathrm{M}$ and in five cells at $25 \mu \mathrm{M}$. L-Glutamate at $25 \mu \mathrm{M}$ was applied alone to every cell before and after testing the effects of CNQX. Currents elicited by a step from -80 to either -10 or $0 \mathrm{mV}$. 
Figure 5. Lack of effect of NMDA receptor agonists. $A$ and $B$, Inhibition of Ba current by $25 \mu \mathrm{M}$ L-glutamate but not $100 \mu \mathrm{M}$ L-aspartate. Pulses from -80 to $0 \mathrm{mV}$ were elicited every $2 \mathrm{sec}$. $C$ and $D$, Inhibition of Ba current by $25 \mu \mathrm{M}$ L-glutamate but not $100 \mu \mathrm{M}$ NMDA, either in the absence or presence of $1 \mu \mathrm{M}$ glycine. NMDA evoked a small increase in holding current when applied together with glycine; the small apparent increase in Ba current at -10 $\mathrm{mV}$ is likely due to current carried by Ba through NMDA receptor-gated channels. Pulses elicited every 2 sec.
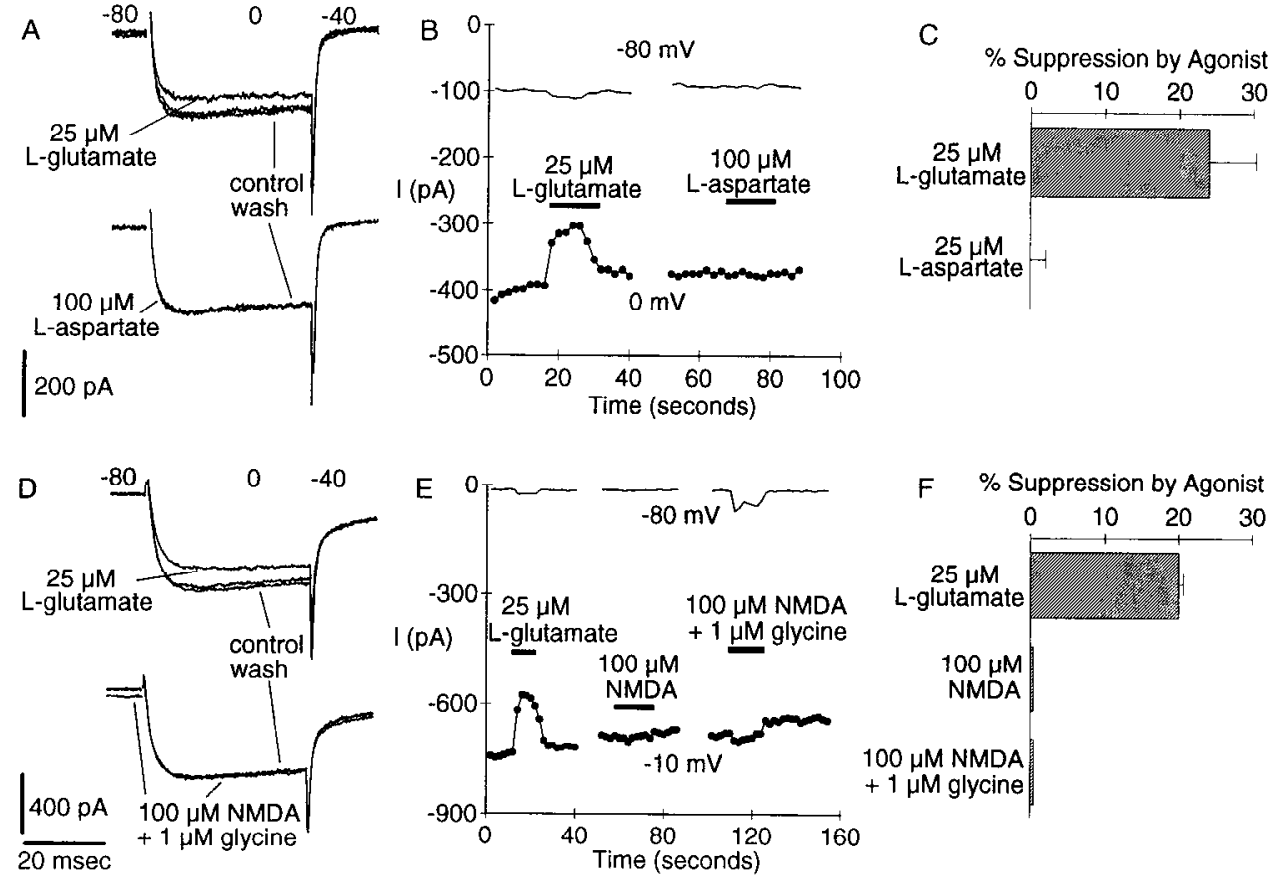

F \% Suppression by Agonist

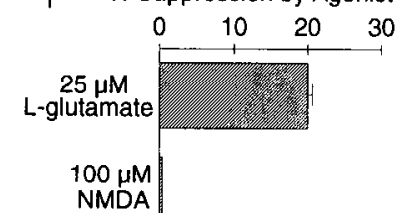

$100 \mu \mathrm{M}$ NMDA

$+1 \mu \mathrm{M}$ glycine
$5 D-C$ ), even when applied together with $1 \mu \mathrm{M}$ glycine (Johnson and Ascher, 1987; Kleckner and Dingledine, 1988), to allow for activation of NMDA receptor-gated cation channels.

The ability of L-AP4 to mimic the actions of L-glutamate was also examined. In 10 cells that responded to L-glutamate $(31 \pm 4.1 \%$ reduction of $\mathrm{Ca}$ channel current), $100 \mu \mathrm{M} \mathrm{L}-\mathrm{AP} 4$ had no effect $(1.3 \pm 0.7 \%$ reduction).

The metabotropic glutamate receptor that mediates $\mathrm{IP}_{3}$ (inositol-1,4,5-trisphosphate) formation responds to L-glutamate, but not kainate, AMPA, or NMDA, and is insensitive to block by CNQX (Sladeczek et al., 1985; Sugiyama et al., 1987, 1989; Palmer et al., 1988; Schoepp and Johnson, 1988; Manzoni et al., 1990), matching the results shown so far for L-glutamate inhibition of Ca channel current. Three other analogs of L-glutamate that act as agonists at metabotropic receptors are quisqualate, ibotenate, and $t$-ACPD (Sladeczek et al., 1985; Nicoletti et al., 1986a,b; Sugiyama et al., 1987; Palmer et al., 1988; Schoepp and Johnson, 1988; Manzoni et al., 1990; Houamed et al., 1991; Masu et al., 1991). Quisqualate is also a non-NMDA receptor agonist, while ibotenate also acts as an agonist at NMDA receptors. $t$-ACPD is a selective agonist at the metabotropic glutamate receptor (Palmer et al., 1988; Manzoni et al., 1990); $1 S, 3 R$-ACPD is thought to be the active enantiomer in racemic $t$-ACPD (Irving et al., 1990).

Ibotenate, $t$-ACPD, and (+)-quisqualate all mimicked the ability of glutamate to cause a rapid and reversible inhibition of the $\mathrm{Ca}$ channel current (Fig. 6A). Although there was steady rundown of the $\mathrm{Ca}$ channel current in the course of this experiment, each agonist suppressed about the same fraction of wholecell current. (+)-Quisqualate and L-glutamate evoked a small increase in holding current, consistent with activation of nonNMDA receptors, while holding current was not affected by ibotenate (which was applied in the absence of glycine) or $t$-ACPD. The lack of effect of $t$-ACPD on holding current is consistent with the idea that it acts selectively at metabotropic glutamate receptors, at least at submillimolar concentrations (Palmer et al., 1988; Manzoni et al., 1990). The suppression of Ca channel current by ACPD was stereoselective. As shown in
Figure $6 B, 1 S, 3 R$-ACPD suppressed whole-cell Ba currents by $30 \%$ while an equal concentration of $1 R, 3 S$-ACPD was without effect. These agonist sensitivities are consistent with mediation of Ca channel inhibition by a metabotropic glutamate receptor.

Figure 7 shows the concentration-response relations for the four agonists. Each agonist was tested at a range of concentrations applied to a single cell, and the inhibition was expressed as a fraction of the maximal inhibition produced in the cell by a saturating concentration, tested in bracketing applications at the beginning and end of the series (e.g., Fig. 7B). The relative affinities of metabotropic agonists, estimated from $\mathrm{EC}_{50}$ values, were $(+)$-quisqualate $(0.11 \mu \mathrm{M})>$ L-glutamate $(1.6 \mu \mathrm{M})>$ ibotenate $(7.8 \mu \mathrm{M})>t$-ACPD $(48 \mu \mathrm{M})$. In addition to being the most potent, $(+)$-quisqualate differed for the other agonists in having a more shallow dose-response curve. The active enantiomer in racemic $t$-ACPD, $1 S, 3 R$-ACPD, had an $\mathrm{EC}_{\mathrm{s}_{0}}$ of 15.5 $\mu \mathrm{M}$ (data not shown; seven determinations in four cells).

Saturating concentrations of all four agonists produced about the same percentage reduction in current. In 13 cells in which all four agonists were applied sequentially, a saturating concentration of quisqualate $(8 \mu \mathrm{M})$ produced a $22 \pm 2.5 \%$ inhibition; the corresponding values for $\mathrm{L}$-glutamate (at $40 \mu \mathrm{M}$ ), ibotenate (at $200 \mu \mathrm{M}$ ), and $t$-ACPD (at $1 \mathrm{mM}$ ) were $24 \pm 2.6 \%, 24 \pm$ $4.0 \%$, and $20 \pm 2.5 \%$, respectively.

L-AP3 has been reported to block noncompetitively the phosphoinositide hydrolysis mediated by the activation of metabotropic glutamate receptors (Schoepp and Johnson, 1989; Schoepp et al., 1990a,b). We tested the possibility that L-AP3 might noncompetitively antagonize $\mathrm{L}$-glutamate suppression of Ca channel current. L-AP3 at $1 \mathrm{mM}$ had no significant effect on Ca channel current $(0.9 \pm 0.1 \%$ reduction; $n=10)$ when applied alone. L-AP3 at $1 \mathrm{mM}$ also had no significant effect on the suppression of Ca channel current produced by $25 \mu \mathrm{M} \mathrm{L}$-glutamate. In 10 cells, $25 \mu \mathrm{M}$ L-glutamate produced a $21 \pm 2 \%$ reduction of $\mathrm{Ca}$ channel current while $25 \mu \mathrm{M} \mathrm{L}$-glutamate plus $1 \mathrm{mM} \mathrm{L-AP3}$ produced a $20 \pm 4.2 \%$ reduction. It appears that L-AP3 does not noncompetitively antagonize the suppression of $\mathrm{Ca}$ channels produced by L-glutamate. Because responses to 

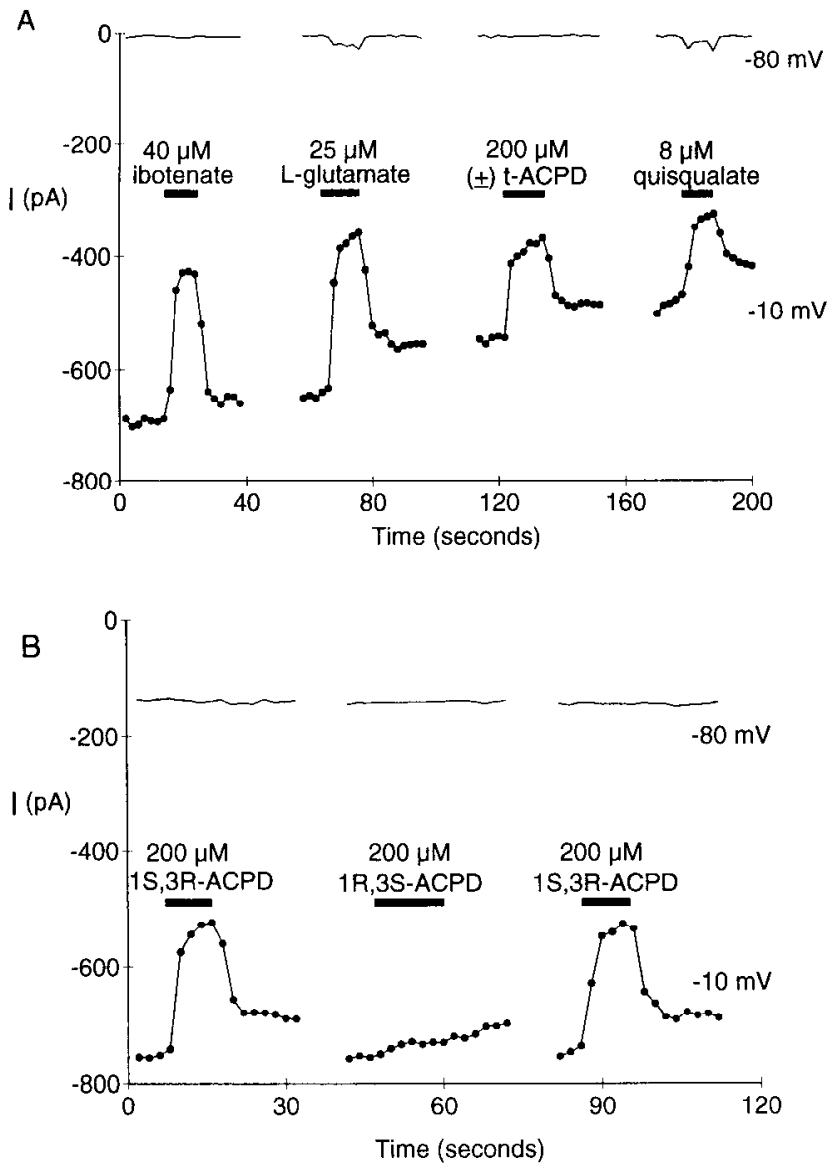

Figure 6. Metabotropic glutamate receptor agonists mimic the inhibition of whole-cell Ba current by L-glutamate. $A$, Effects of $40 \mu \mathrm{M}$ ibotenate, $25 \mu \mathrm{M}$ L-glutamate, $200 \mu \mathrm{M}$ racemic $t$-ACPD, and $8 \mu \mathrm{M}$ (+)-quisqualate on Ba current in the same neuron. In this cell, both L-glutamate and quisqualate evoked a small increase in holding current, consistent with their agonist actions at non-NMDA receptor channels. Ibotenate did not alter the holding current at $-80 \mathrm{mV}$, presumably because no glycine was present (see Fig. 5). Pulses from -80 to -10 $\mathrm{mV}$ were elicited every $2 \mathrm{sec}$. $B$, Comparison of the effects of two enantiomers in racemic $t$-ACPD, $1 S, 3 R$-ACPD, and $1 R, 3 S$-ACPD. Steps from -80 to $0 \mathrm{mV}$ were delivered every $2 \mathrm{sec}$.

half-maximal concentrations of agonists can be rather small, we used concentrations of L-glutamate that were nearly saturating (25 $\mu \mathrm{M}$; see Fig. 7), so we cannot rule out a weak competitive action of L-AP3.

\section{What types of Ca channels does the metabotropic receptor inhibit?}

Hippocampal pyramidal neurons have multiple types of highthreshold Ca channels (Takahashi et al., 1989; Fisher et al., 1990; Toselli and Taglietti, 1990; Mogul and Fox, 1991; O'Dell and Alger, 1991; Regan et al., 1991; Thompson and Wong, 1991; Mintz et al., 1992). At the whole-cell level, different components of high-threshold current are probably best distinguished from each other using pharmacological tools, since it is likely that currents carried by distinct channels overlap in their voltage dependence and kinetics, as in peripheral neurons (Plummer et al., 1989; Regan et al., 1991). In agreement with a previous report using guinea pig CA3 pyramidal neurons (Mogul and Fox, 1991), we find that rat CA3 pyramidal neurons have a relatively large component of high-threshold current ( $25-40 \%)$ inhibited by dihydropyridine blockers. The dihydropyridine-
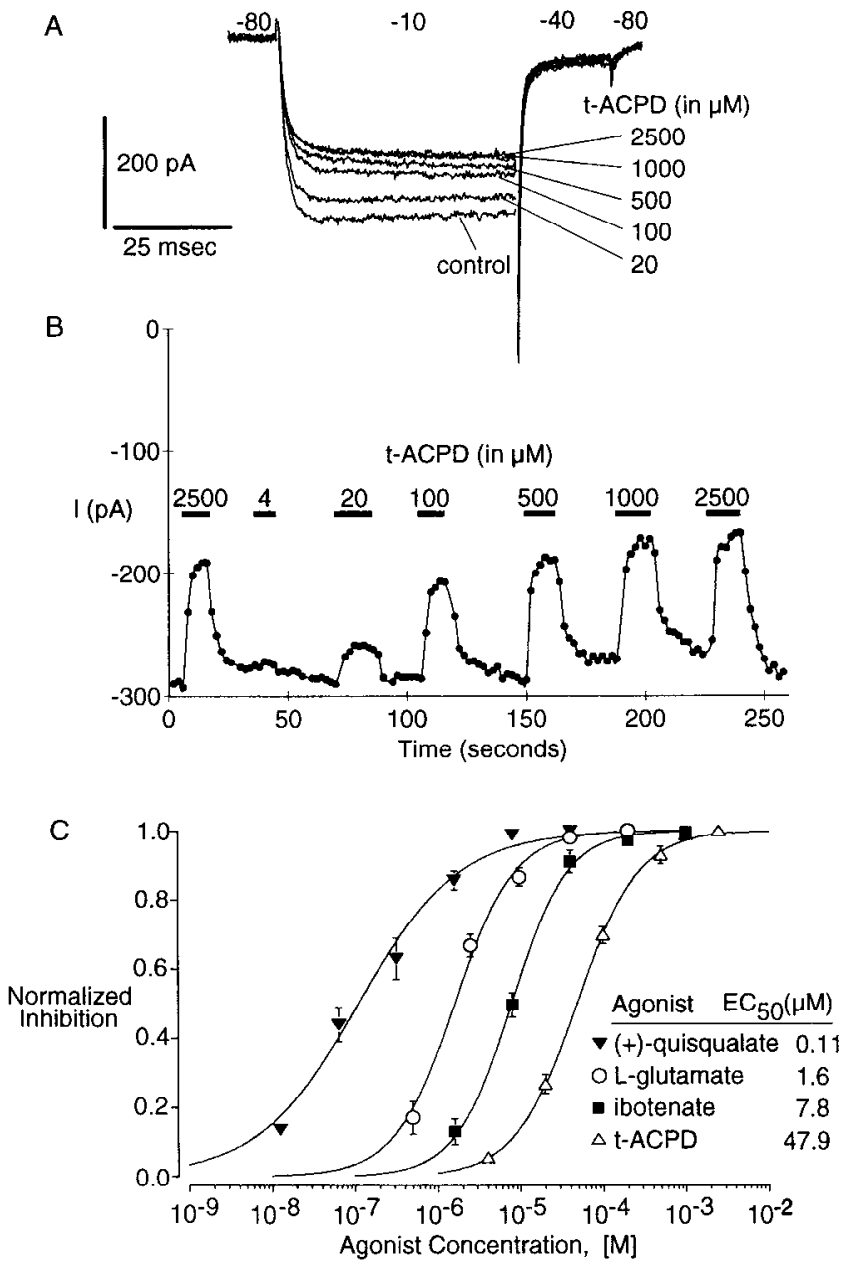

Figure 7. Concentration-response relations for inhibition of wholecell $\mathrm{Ba}$ current by metabotropic glutamate receptor agonists. $A$ and $B$, Inhibition of Ba currents by concentrations of racemic $t$-ACPD from $4 \mu \mathrm{M}$ to $2.5 \mathrm{mM}$. There was little change in the response to a saturating concentration $(2.5 \mathrm{mM}$ ) of $t$-ACPD bracketing the other concentrations. Voltage steps from -80 to $0 \mathrm{mV}$ were delivered every $2 \mathrm{sec}$. $C$, Collected data for the concentration-response relations for quisqualate, L-glutamate, ibotenate, and $t$-ACPD. Experiments like that in $A$ and $B$ were done in four to six cells for each agonist. The amount of inhibition produced by each concentration was expressed as a fraction of the effect produced by a saturating concentration of the agonist in the same cell. Data points show mean \pm SEM for a total of 11 determinations in six cells for each concentration of $(+)$-quisqualate, 6 determinations in four cells for L-glutamate, 8 determinations in five cells for ibotenate, and 11 determinations in four cells for $t$-ACPD. Smooth curves are drawn according to the following: normalized inhibition $=1 /\left[1+\left(\mathrm{EC}_{50} /[\mathrm{ag}-\right.\right.$ onist]) $)^{n}$, with $\mathrm{EC}_{50}=0.11 \mu \mathrm{M}, n=0.71$ for (+)-quisqualate; $\mathrm{EC}_{50}=$ $1.62 \mu \mathrm{M}, n=1.2$ for L-glutamate; $\mathrm{EC}_{50}=7.8 \mu \mathrm{M}, n=1.3$ for ibotenate; and $\mathrm{EC}_{50}=47.9 \mu \mathrm{M}, n=1.2$ for racemic $t$-ACPD. The active enantiomer $1 S, 3 R$-ACPD had an $\mathrm{EC}_{50}$ of $15.5 \mu \mathrm{M}$ with a slope $(n)$ of 1.12 (seven determinations in four cells; data not shown).

sensitive current flows though high-conductance L-type channels detected at the single-channel level (Mogul and Fox, 1991; data not shown). We find that the N-type channel blocker $\omega$-CgTx-GVIA blocks about $25-45 \%$ of the high-threshold current in CA3 neurons (e.g., Figs. 8C, 11). Like most other neurons (Regan et al., 1991), hippocampal CA3 neurons also possess high-threshold current that is resistant to saturating concentrations of dihydropyridines and $\omega$-CgTx-GVIA. A small fraction of this current can be blocked by $\omega$-Aga-IVA, a peptide toxin from spider venom that is a selective blocker of P-type channels 
A

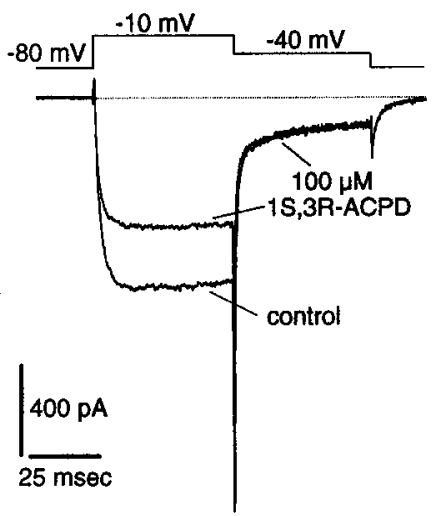

B

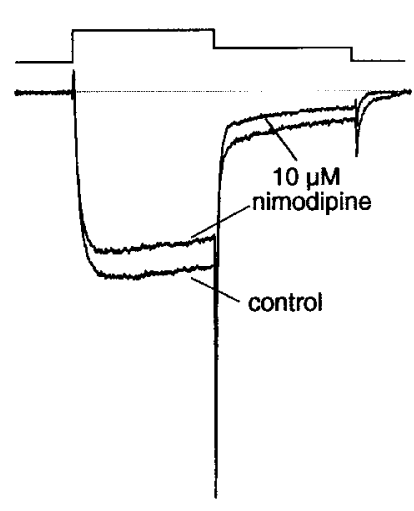

C

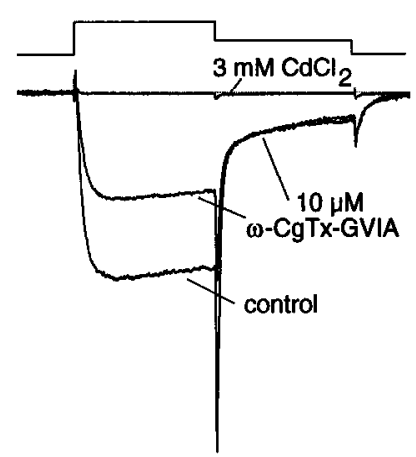

D

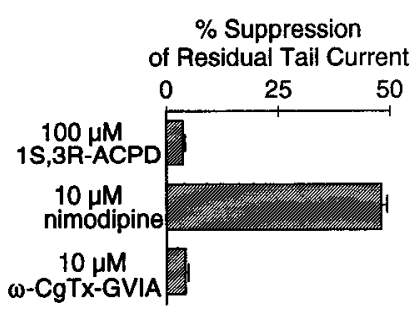

Figure 8. Lack of effect of $1 S, 3 R$-ACPD on dihydropyridine-sensitive tail currents. $A$, Whole-cell Ba currents recorded in control and $6 \mathrm{sec}$ after application of $1 S, 3 R$-ACPD. $B$, Current from the same cell as in $A$ before and $15 \mathrm{sec}$ following the application of $10 \mu \mathrm{M}$ nimodipine. $C$, Same cell as in $A$ and $B$ hefore and after application of either $10 \mu \mathrm{M}$ $\omega$-CgTx-GVIA or $3 \mathrm{mM} \mathrm{CdCl}$. $D$, Pooled results from 11 neurons showing the effe.ts of $1 S, 3 R$-ACPD, nimodipine, and $\omega$-CgTx-GVIA on the current measured $30 \mathrm{msec}$ after repolarization to $-40 \mathrm{mV}$ from a test potential of either 0 or $-10 \mathrm{mV}$. The holding potential in all cells was $-80 \mathrm{mV}$. The mean suppression of peak test current by $100 \mu \mathrm{M}$ $1 S, 3 R$-ACPD was $27 \pm 2.7 \%$. No low-threshold current was seen in any of these cells when stepping from $-110 \mathrm{mV}$ to $-50 \mathrm{mV}$. All currents are shown after leak subtraction using current elicited by a step from $-80 \mathrm{mV}$ to $-90 \mathrm{mV}$.

(Mintz et al., 1992); based on sensitivity to $\omega$-Aga-IVA, an average of only $14 \%$ of the high-threshold current in CA3 pyramidal neurons is contributed by P-type channels (Mintz et al., 1992). While none of these pharmacological tools are perfect (in particular, it remains to be seen whether individual channel types are completely blocked by saturating concentrations of the agents), they have been shown to target fractions of high-threshold current that show little overlap in sensory, cerebellar Purkinje, superior cervical sympathetic, and CA1 pyramidal neurons (Aosaki and Kasai, 1989; Takahashi et al., 1989; Mogul and Fox, 1991; Regan et al., 1991; Mintz et al., 1992). We focused on examining the actions of $1 S, 3 R$-ACPD on L-type and N-type channels.

Figures 8-10 illustrate three independent experimental approaches designed to address whether L-type channels are modulated by activation of the metabotropic glutamate receptor. First, in most CA3 pyramidal neurons, when the voltage was stepped to near $0 \mathrm{mV}$ and then repolarized to $-40 \mathrm{mV}$, deactivation of current was incomplete at $-40 \mathrm{mV}$; with further repolarization to $-80 \mathrm{mV}$, the current deactivated completely
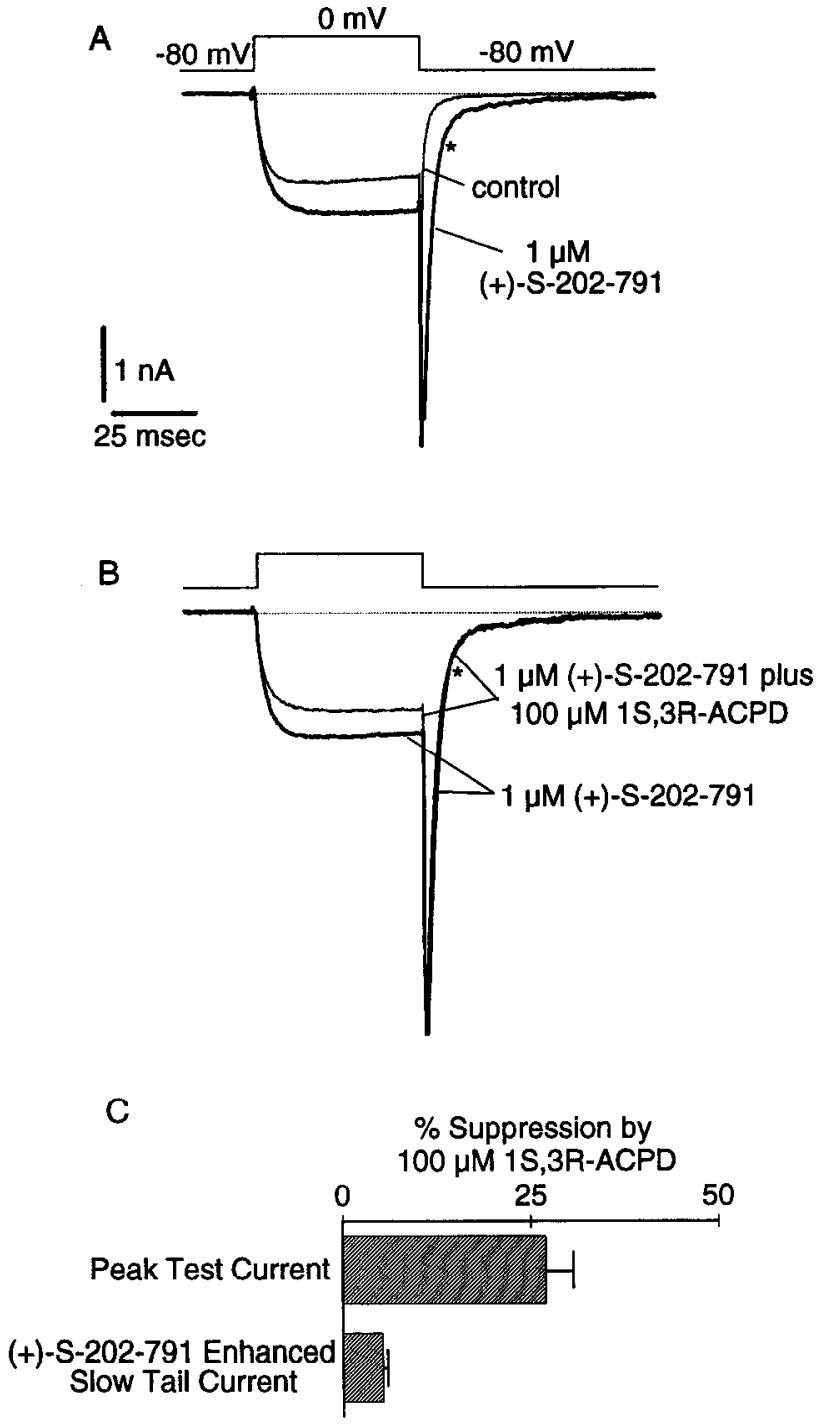

Figure 9 . Slow tail currents enhanced by dihydropyridine agonists are not suppressed by $1 S, 3 R$-ACPD. $A$, Whole-cell Ba currents recorded in control and $16 \mathrm{sec}$ after application of $(+)-S-202-791 . B$, Currents from the same cell as in $A$ before and $6 \mathrm{sec}$ following the application of $1 S, 3 R$ ACPD while continuously in the presence of $(+)-S-202-791$. $C$, Pooled results from five neurons showing the effects of $1 S, 3 R-\mathrm{ACPD}$ on $(+)-$ S-202-791 slow tail currents and peak test currents. Slow tails were measured at $5 \mathrm{msec}$ (denoted by asterisk on current records) after repolarization to $-80 \mathrm{mV}$ from a test potential of $0 \mathrm{mV}$. The holding potential in all cells was $-80 \mathrm{mV}$. All currents are shown after leak substraction by extrapolation from negative potentials. The broken line represents zero current.

with a slow tail current having a time constant of $\sim 3 \mathrm{msec}$. Both the residual current at $-40 \mathrm{mV}$ and the slow tail current at $-80 \mathrm{mV}$ are partially blocked by nimodipine but are insensitive to $\omega$-CgTx-GVIA, suggesting that these current components are carried at least in part by L-type channels (Fig. $8 \mathrm{~A}-$ $C)$. We tested whether $1 S, 3 R$-ACPD suppressed these current components. In 11 neurons, application of $100 \mu \mathrm{M} 1 S, 3 R$-ACPD caused a $27 \pm 2.7 \%$ inhibition of the test current measured at $0 \mathrm{mV}$ while having almost no effect $(3.7 \pm 1.3 \%$ inhibition) on the residual current measured $30 \mathrm{msec}$ after repolarization to $-40 \mathrm{mV}$ (see Fig. 8). In these same neurons, $10 \mu \mathrm{M}$ nimodipine blocked the residual current at $-40 \mathrm{mV}$ by $48 \pm 2.7 \%$, while $10 \mu \mathrm{M} \omega$-CgTx-GVIA was without much effect $(4.3 \pm 1.9 \%$ decrease). The slow tail current present on repolarization from 
A

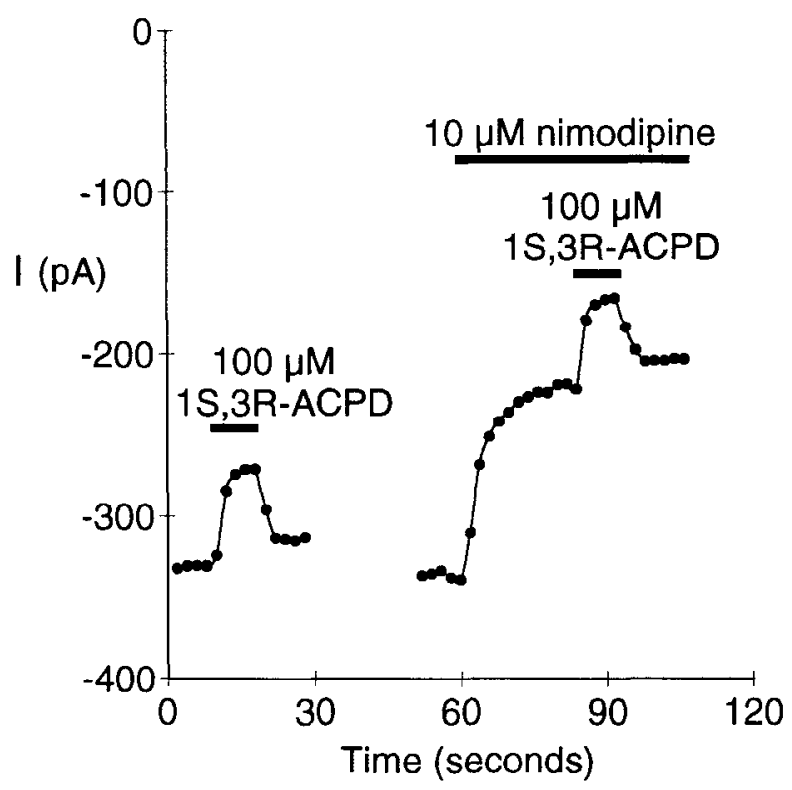

B

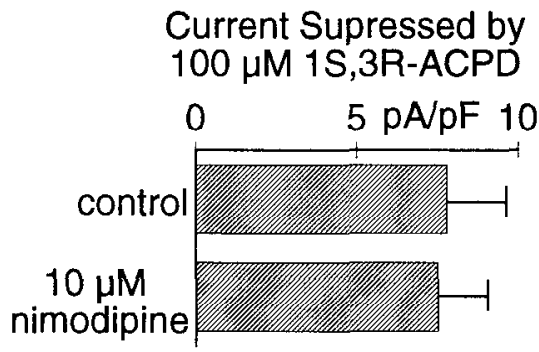

Figure 10. Dihydropyridine antagonists do not occlude $1 S, 3 R$-ACPD suppression of whole-cell Ba currents in CA3 pyramidal neurons. $A$, Time course of the effects of $1 S, 3 R$-ACPD on Ba currents before and after application of nimodipine. Ba current weres evoked by depolarizations to $0 \mathrm{mV}$. Holding potential was $-80 \mathrm{mV}$. Test pulses were given every $2 \mathrm{sec}$. $B$, Pooled data from six neurons for the mean current (normalized to the cell capacitance) suppressed by $100 \mu \mathrm{M} 1 S, 3 R$-ACPD before and after block of the nimodipine-sensitive fraction of wholecell Ba current. Mean nimodipine block was $31 \pm 2.3 \%$. 1S,3R-ACPD suppressed $19 \pm 1.1 \%$ of the whole-cell Ba current before and $25 \pm$ $1.1 \%$ after nimodipine block.

-40 to $-80 \mathrm{mV}$ was also partially inhibited by nimodipine but not by $\omega$-CgTx-GVIA or $1 S, 3 R$-ACPD.

Similar results were obtained for dihydropyridine agonistenhanced lail currents in five neurons. Figure 9 shows that 1 $\mu \mathrm{M}(+)-S-202-791$ greatly enhanced a slow tail current component elicited when repolarizing from $0 \mathrm{mV}$ to $-80 \mathrm{mV}$. As in other neurons, enhancement of the slow tail current by the dihydropyridine agonist can likely be attributed to long openings of L-type Ca channels induced by the drug (Nowycky et al., 1985; Plummer et al., 1989). 1S,3R-ACPD at $100 \mu \mathrm{M}$ suppressed $27 \pm 4.5 \%$ of the test current measured at $0 \mathrm{mV}$ while having little or no effect on the slow tail current components (5.3 $\pm 1.4 \%$ inhibition; see Fig. 9), suggesting that agonistenhanced L-type channels are not affected by $1 S, 3 R$-ACPD. Finally, we tested whether the dihydropyridine antagonist nimodipine could occlude the suppression of high-threshold current by $1 S, 3 R$-ACPD. In six neurons, $10 \mu \mathrm{M}$ nimodipine blocked
A

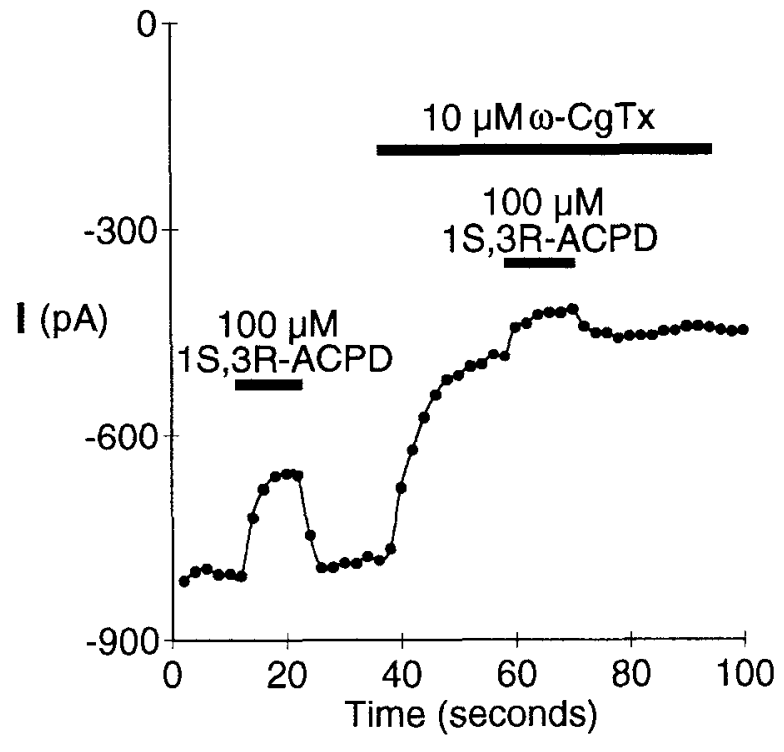

B

\section{Current Suppressed by $100 \mu \mathrm{M}$ 1S,3R-ACPD}

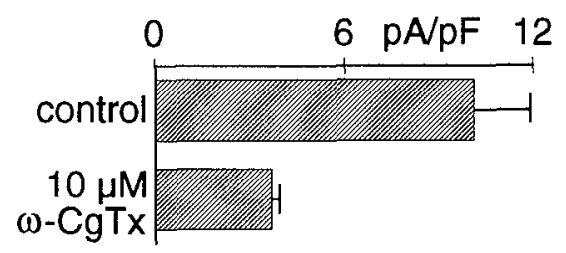

Figure 11. 1S,3R-ACPD suppresses $\omega$-CgTx-GVIA-sensitive $\mathrm{Ca}$ channels. $A$, Time course of the effects of $1 S, 3 R$-ACPD on Ba currents before and after application of $\omega$-CgTx-GVIA. Ba currents were evoked by depolarizations to $0 \mathrm{mV}$. Holding potentials was $-80 \mathrm{mV}$. Test pulses were given every 2 sec. $B$, Pooled data from six neurons for the mean current (normalized to the cell capacitance) suppressed by $100 \mu \mathbf{M} 1 S, 3 R$ ACPD before and after block of the $\omega$-CgTx-GVIA-sensitive fraction of whole-cell Ba current. Mean $\omega$-CgTx-GVIA block was $36.3 \pm 1.7 \%$. $1 S, 3 R$-ACPD suppressed $23 \pm 3.9 \%$ of the whole-cell Ba current before and $12.9 \pm 1.9 \%$ after $\omega$-CgTx-GVIA block.

$31 \pm 2.3 \%$ of the Ba current elicited by stepping from -80 to near $0 \mathrm{mV}$. The Ca channel current suppressed by $1 S, 3 R$-ACPD (expressed as $\mathrm{pA}$ of current per $\mathrm{pF}$ of cell capacitance) was measured before and after nimodipine block. IS,3R-ACPD at $100 \mu \mathrm{M}$ suppressed $7.8 \pm 2.0 \mathrm{pA} / \mathrm{pF}$ of current prior to nimodipine application and $7.5 \pm 2.3 \mathrm{pA} / \mathrm{pF}$ of current after block by nimodipine (Fig. 10), suggesting that almost none of the current suppressed by $1 S, 3 R$-ACPD could be blocked by nimodipine.

These three results all suggest that L-type current is not suppressed by metabotropic glutamate receptor agonists.

Figure 11 shows that $\omega$-CgTx-GVIA and 1S,3R-ACPD act on the same fraction of Ca channel current in CA3 pyramidal neurons. In six neurons, $10 \mu \mathrm{M} \omega$-CgTx-GVIA blocked $36.3 \pm$ $1.7 \%$ of the Ba current elicited by stepping from -80 to near 0 $\mathrm{mV}$. $1 S, 3 R$-ACPD $(100 \mu \mathrm{M})$ suppressed $10.2 \pm 2.0 \mathrm{pA} / \mathrm{pF}$ of current prior to $\omega$-CgTx-GVIA application and $3.7 \pm 0.3 \mathrm{pA} /$ pF of current after block by $\omega$-CgTx-GVIA (see Fig. 11). We conclude that the major portion of the current suppressed by $1 S, 3 R-A C P D$ is of the $\mathrm{N}$ type. 

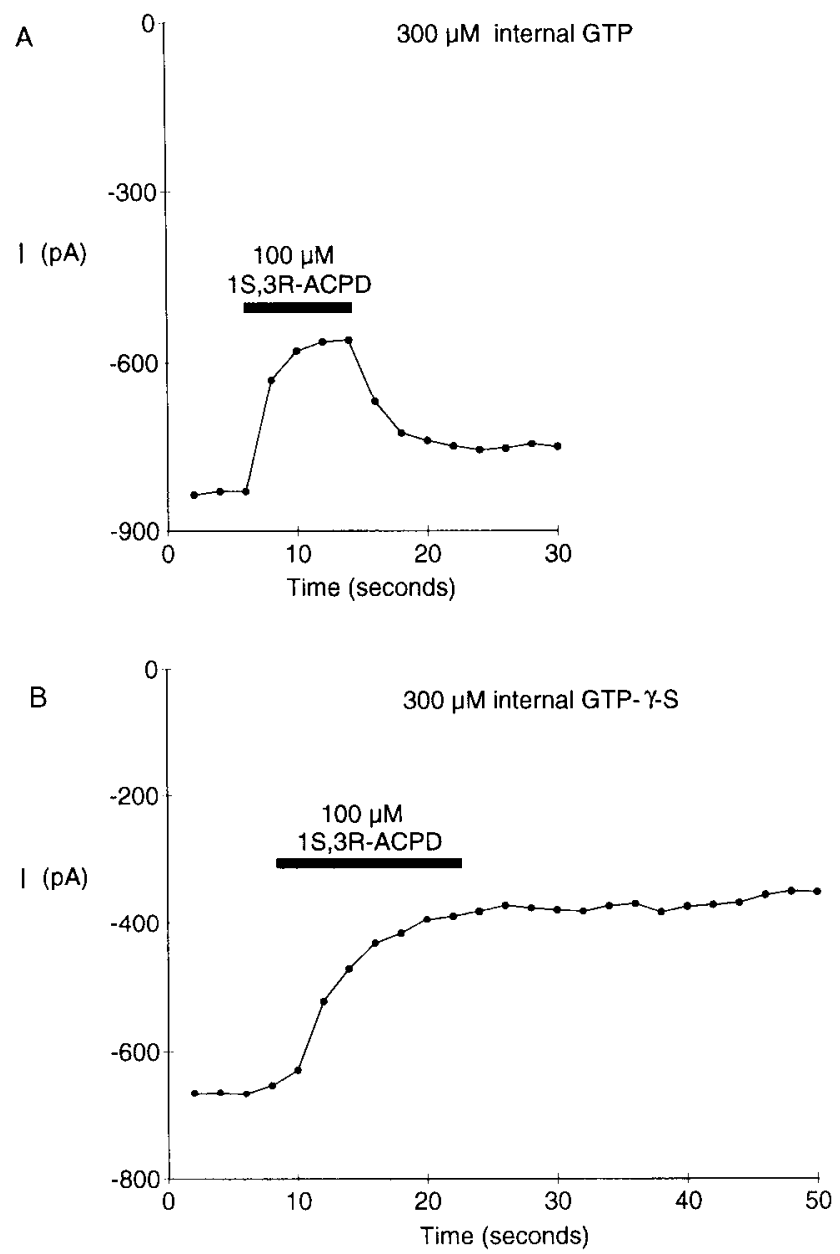

Figure 12. A G-protein couples metabotropic glutamate receptors to Ca channels. $A$, Time course for the effect of $1 S, 3 R$-ACPD on wholecell Ba current in a cell dialyzed for 11 min with $300 \mu \mathrm{M}$ GTP. $B$, Same experiment as in $A$ but for a different cell dialyzed with $300 \mu \mathrm{M}$ GTP$\gamma-\mathrm{S}$ for $13 \mathrm{~min}$. The irreversibility of suppression in the presence of GTP- $\gamma-\mathrm{S}$ was seen in nine other neurons. Ba current were cvoked by depolarizations to $-10 \mathrm{mV}$. Holding potential was $-80 \mathrm{mV}$. Test pulses were given every $2 \mathrm{sec}$.

While the suppression of current by $1 S, 3 R$-ACPD was dramatically less after block of $\omega$-CgTx-GVIA-sensitive current, the inhibition by $1 S, 3 R$-ACPD was not completely occluded. Approximately $60-70 \%$ of the whole-cell current in these cells can be accounted for by dihydropyridine-sensitive (L-type) and $\omega$-CgTx-GVIA-sensitive (N-type) channel populations. In most CA3 cells, the P-type channel blocker $\omega$-Aga-IVa blocks little of the remaining $30-40 \%$ of the high-voltage-activated current (Mintz et al., 1992). We tested the ability of $\omega$-Aga-IVa to block $\mathrm{Ca}$ channels in $\mathrm{CA} 3$ cells under the conditions of the present study (with $25 \mathrm{mM} \mathrm{BaCl}{ }_{2}$ rather than the $5 \mathrm{mM} \mathrm{BaCl}_{2}$ used by Mintz et al., 1992). In five cells, $200 \mathrm{nM} \omega-\Lambda$ ga-IVa blocked only $5 \pm 1 \%$ of the whole-cell Ca current. In four additional $\mathrm{CA} 3$ cells, $200 \mathrm{nM} \omega$-Aga-IVa produced no quantifiable block. Because of the small effect of $\omega$-Aga-IVa, it was impossible to determine if the small fraction of $\mathrm{P}$-type current present in some cells could be modulated by $1 S, 3 R$-ACPD. It seems clear that P-type current could account for only a very small fraction, if any, of the Ca channel current modulated by the metabotropic glutamate receptor.

\section{Coupling between receptor and channel involves $G$-proteins}

We tested for the involvement of a G-protein in the coupling between metabotropic glutamate receptors and Ca channels in CA3 pyramidal neurons by comparing cells dialyzed with GTP and its nonhydrolyzable analog, GTP- $\gamma$-S. In neurons dialyzed with $300 \mu \mathrm{M}$ GTP, the suppression of $\mathrm{Ca}$ channel current by $100 \mu \mathrm{M} 1 S, 3 R$-ACPD was readily reversible (Fig. 12). In contrast, if cells were dialyzed for $10-15$ min with $300 \mu \mathrm{M}$ GTP. $\gamma-\mathrm{S}$, the suppression of Ca channel current by $1 S, 3 R$-ACPD was irreversible (Fig. 12; $n=9$ ). This suggests that a G-protein is involved in the coupling between receptor and channel.

Neurons express numerous distinct G-protein subunits, some of which are sensitive to ribosylation by islet-activating protein (pertussis toxin) (Ui, 1984). We compared the ability of pertussis toxin to block the coupling between several different neurotransmitter receptors and $\mathrm{Ca}$ channels in these neurons. Somatostatin, baclofen, and 2-Cl-adenosine were tested along with $1 S, 3 R-\mathrm{ACPD}$, as they have been reported to couple via pertussis toxin-sensitive G-proteins to $\mathrm{Ca}$ channels in numerous different types of neurons (Holz et al., 1986; Lewis et al., 1986; Gross et al., 1989; Ikeda and Schofield, 1989; Sah, 1990; Kleuss et al., 1991; Scholz and Miller, 1991a,b). We tried to use pertussis toxin on acutely dissociated CA3 cells with two different approaches. First, the A protomer was included in the patch pipette at concentrations of $2 \mu \mathrm{g} / \mathrm{ml}$ in the presence of $2 \mathrm{mM}$ nicotinamide adenine dinucleotide and $4 \mathrm{mM}$ ATP. In four cells dialyzed for 20-60 min with A protomer, $1 S, 3 R$-ACPD, baclofen, 2-Cl-adenosine, and somatostatin still inhibited Ca channel current, with no diminution in response during the recording. Second, the holoenzyme of pertussis toxin $(1 \mu \mathrm{g} / \mathrm{ml})$ was applied to hippocampal slices for $5 \mathrm{hr}$ at $37^{\circ} \mathrm{C}$ (the longest that slices remained viable at this temperature). In three cells treated in this manner, no significant reduction in response to $1 S, 3 R$ ACPD, baclofen, 2-Cl-adenosine, or somatostatin was seen when comparcd to control cells. Neither of these approaches showed a significant effect of pertussis toxin on baclofen, 2-Cl-adenosine, or somatostatin responses, previously reported to be sensitive to the toxin. We conclude that pertussis toxin probably was not active under the conditions we used it, and our results leave open the possibility that the suppression of $\mathrm{Ca}$ channels by metabotropic glutamate receptors is pertussis toxin sensitive.

\section{Spatial restriction for coupling between receptor and $\mathrm{Ca}$ channels}

In some instances the coupling between neurotransmitter receptors and $\mathrm{Ca}$ channels involves diffusible second messengers (Reuter, 1983; Fisher and Johnston, 1990; Bernheim et al., 1991 a). In contrast, in other cases the coupling between receptor and channel is physically restricted (Forscher and Oxford, 1985; Lipscombe et al., 1989; Bernheim et al., 199 la). We investigated these possibilities by employing outsidc-out ccll-frec membrane patch and cell-attached patch techniques.

Outside-out patches containing many Ca channels could be obtained from CA3 pyramidal neurons in which rundown of current was small over the course of 10-15 min. Semimacroscopic Ba currents from outside-out patches were rapidly and reversibly suppressed by application of $1 S, 3 R$-ACPD, baclofen, 

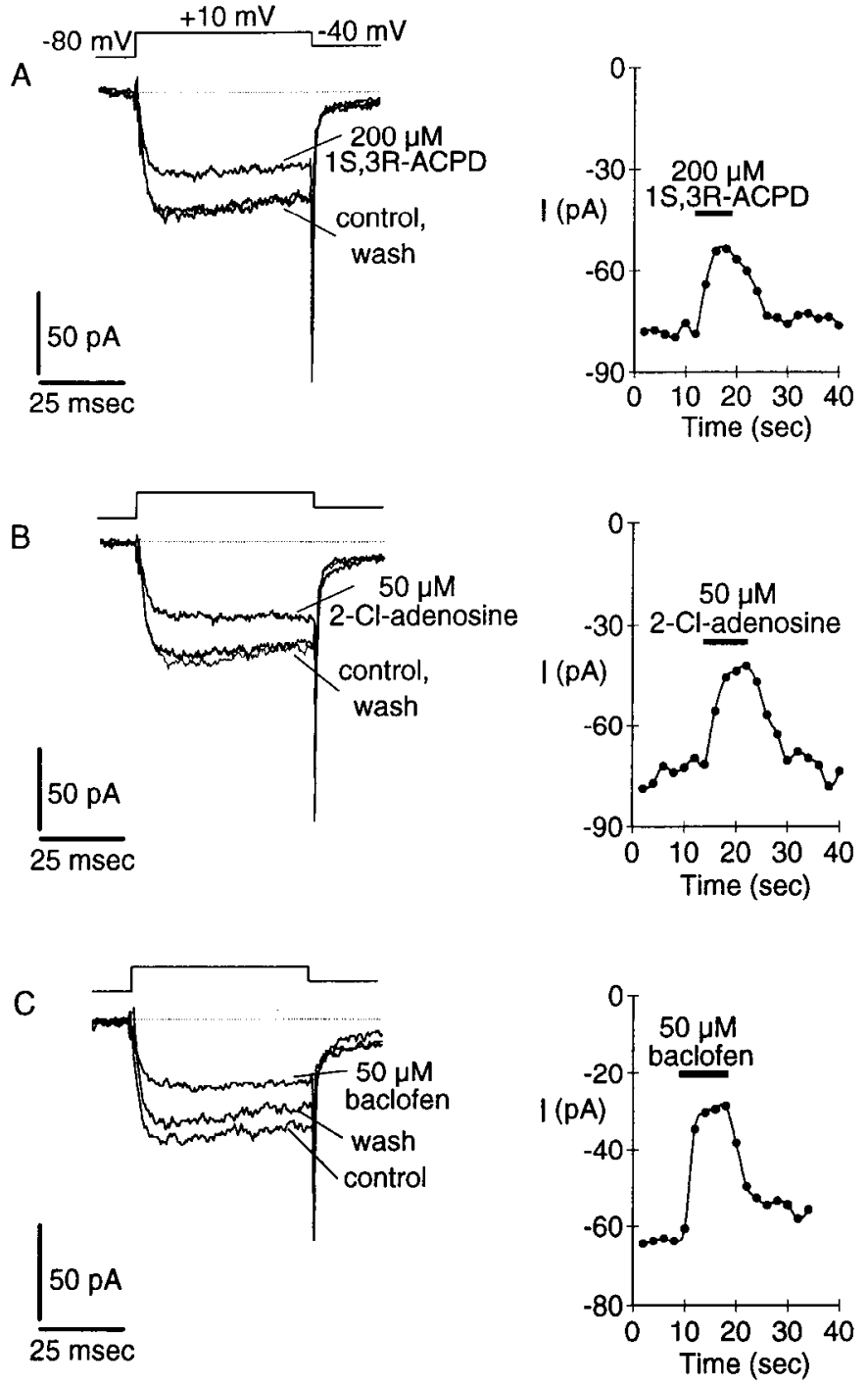

Figure 13. Suppression of macroscopic Ba currents in outside-out membrane patches. $A$, Effects of $1 S, 3 R$-ACPD on macroscopic Ba currents from a outside-out membrane patch. The patch was pulled from a CA3 pyramidal neuron $6 \mathrm{~min}$ prior to the time course shown. $B$, Effects of 2-Cl-adenosine on Ba currents from the same patch as in $A$ but $7 \mathrm{~min}$ after patch formation. $C$. Effects of baclofen on Ba currents from the same patch as in $A$ and $B$ but 8 min after patch formation. In all cases, Ba currents were elicited by voltage steps from -80 to +10 $\mathrm{mV}$ given every $2 \mathrm{sec}$. Currents are shown after leak subtraction by extrapolating from negative potentials. In this patch, the leak currents at $-80 \mathrm{mV}$ were $\sim 10 \mathrm{pA}$. Broken lines represent 0 current.

or 2-Cl-adenosine to the external face of the membrane (Fig. $13)$. In the patch shown in Figure $13,1 S, 3 R$-ACPD, 2-Cl-adenosine, and baclofen were applied 6,7 , and 8 min following outside-out patch formation, respectively. In another patch, transmitter suppression of Ca current could be seen $15 \mathrm{~min}$ following patch formation. Similar results with these three transmitter analogs were seen in four other outside-out patches.

To determine if the coupling between metabotropic glutamate receptors and $\mathrm{Ca}$ channels involves a diffusible second messenger, we examined whether channels in cell-attached patches could be modulated by activation of receptors in the plasma mem-
A
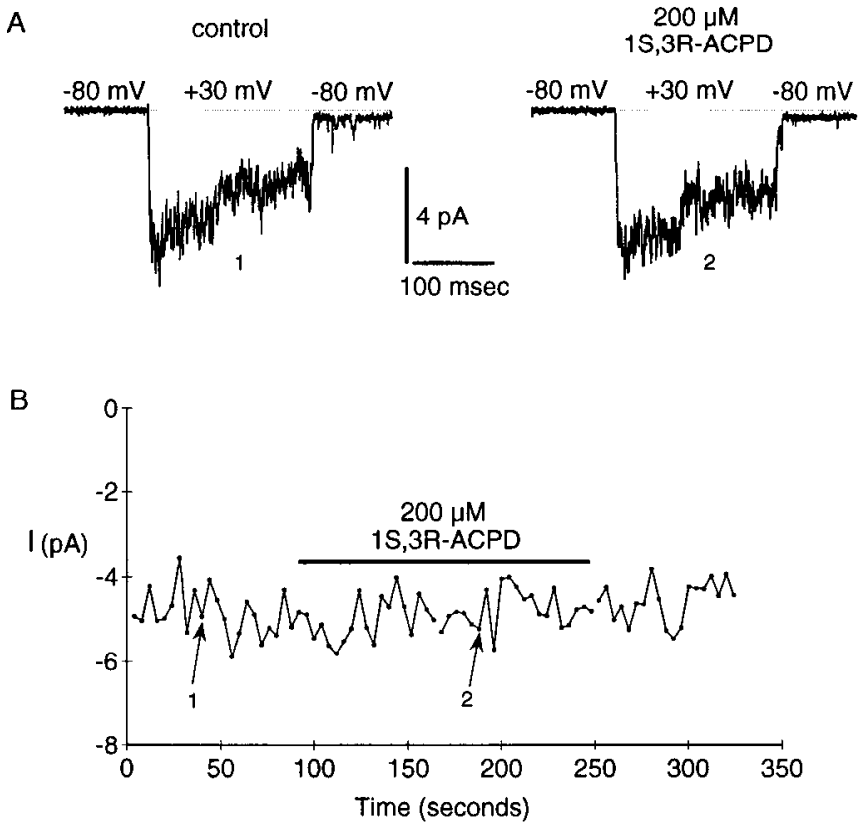

Figure 14. 1S,3R-ACPD does not suppress macroscopic Ba currents in cell-attached membrane patches when applied outside the patch membrane. $A$, Sample traces showing macroscopic Ba currents before and after application of $1 S, 3 R$-ACPD to the cell membrane outside the cell-attached patch. $B$, Time course of the effects of $1 S, 3 R$-ACPD on macroscopic Ba currents. Currents were evoked by voltage steps from -80 to $+30 \mathrm{mV}$ every $4 \mathrm{sec}$. $1 S, 3 R$-ACPD was applied for $2.5 \mathrm{~min}$. Currents are shown after leak subtraction by extrapolating from negative potentials. In this patch, the leak currents at $-80 \mathrm{mV}$ were $\sim 1 \mathrm{pA}$. Broken lines represent 0 current.

brane outside of the patch. Cell-attached patch recordings were made with $110 \mathrm{mM} \mathrm{BaCl}$ inside the pipette while the cell was bathed in a $145 \mathrm{mM} \mathrm{K}$-gluconate solution to zero the membrane potential. Single-channel activity could routinely be seen in these patches. On occasion, many channels were present, giving semimacroscopic Ba currents having amplitudes of $\sim 5-10 \mathrm{pA}$. Figure 14 shows a cell-attached patch recording from a CA3 pyramidal neuron. When voltage steps were evoked to $+30 \mathrm{mV}$ for $300 \mathrm{msec}$ from a holding potential of $-80 \mathrm{mV}$, Ba currents were about $5 \mathrm{pA}$, corresponding to $\sim 10-20 \mathrm{Ca}$ channels. Individual openings and reopenings could be seen in the tail after repolarization to $-80 \mathrm{mV}$ (Fig. $14 A$ ). After sampling macroscopic Ba currents for $2 \mathrm{~min}, 200 \mu \mathrm{M} 1 S, 3 R$-ACPD was applied for $2.5 \mathrm{~min}$ to the cell membrane outside of the cell-attached patch. As shown in Figure 14, the application of $1 S, 3 R$-ACPD did not significantly alter the magnitude of the macroscopic $\mathrm{Ba}$ currents $(4.7 \pm 0.09 \mathrm{pA}$ in control and $4.9 \pm 0.08 \mathrm{pA}$ in $1 S, 3 R$ ACPD). In two other cell-attached patches where macroscopic Ba currents could be measured, $1 S, 3 R$-ACPD application was also without significant effect $(0.1 \%$ reduction in Ba current).

Other cell-attached patches contained only a few Ca channels. In four of these patches, $\mathrm{Ca}$ channel activity displayed short open times, bursting activity, and a conductance of $15-18 \mathrm{pS}$, even in the presence of $1 \mu \mathrm{M}(+)-S-202-791$. We tentatively designated this activity as $\mathrm{N}$-type, possibly corresponding to the $\omega$-CgTx-GVIA-sensitive fraction of whole-cell Ca channel current. In order to examine the effects of $1 S, 3 R$-ACPD, the chan- 
nel activity was quantified by calculating the average current in $300 \mathrm{msec}$ test pulses. In these four patches, the mean activity (stepping from $-80 \mathrm{mV}$ to either 0 or $+10 \mathrm{mV}$ ) was $0.13 \pm$ $0.03 \mathrm{pA}$ in control solutions and $0.14 \pm 0.04 \mathrm{pA}$ after application of $200 \mu \mathrm{M} 1 S, 3 R$-ACPD. In the presence of $1 \mu \mathrm{M}(+)$ $\mathrm{S}-202-791$, three other patches displayed N-channel activity together with long $30 \mathrm{pS}$ openings, presumably corresponding to L-channels. In these patches, the mean activity was $0.19 \pm$ $0.03 \mathrm{pA}$ in control solution and $0.25 \pm 0.05 \mathrm{pA}$ after application of $200 \mu \mathrm{M} 1 S, 3 R$-ACPD.

From the cell-attached experiments, we conclude that $1 S, 3 R$ ACPD applied to the cell membrane outside the patch did not suppress channels isolated in the patch. These results suggest that the coupling between metabotropic glutamate receptors, $\mathrm{G}$-proteins, and $\mathrm{Ca}$ channels occurs in a physically restricted manner, and that a readily diffusible second messenger is not likely to be involved.

\section{Discussion}

Our results confirm the earlier reports by Lester and Jahr (1990) and Chernevskaya et al. (1991) that stimulation of glutamate receptors can suppress current through voltage-dependent $\mathrm{Ca}$ channels in hippocampal neurons.

\section{Glutamate receptor type}

In particular, our results support the suggestion by Lester and Jahr (1990) that the metabotropic glutamate receptor inhibits hippocampal $\mathrm{Ca}$ channels. In agreement with their results, quisqualate displayed agonist properties while NMDA, AMPA, and kainate were without effect, and (unlike quisqualate-activated cation channels) the response was not blocked by CNQX. The reversibility of the inhibition in our experiments allowed us to obtain concentration-response data for the agonists. The affinities $\left(\mathrm{EC}_{50}\right.$, half-maximal concentration) of the four agonists for inhibition of hippocampal $\mathrm{Ca}$ channels $[(+)$-quisqualate $(0.11$ $\mu \mathrm{M})>$ L-glutamate $(1.6 \mu \mathrm{M})>$ ibotenate $(7.8 \mu \mathrm{M})>t$-ACPD $(48 \mu \mathrm{M})$ ] are remarkably similar to those recently reported by Masu et al. (1991) for the ability of a cloned metabotropic receptor to stimulate $\mathrm{Ca}$-activated $\mathrm{Cl}^{-}$current when expressed in Xenopus oocytes [quisqualate $(0.2 \mu \mathrm{M})>$ ibotenate $(6 \mu \mathrm{M})$ $>$ L-glutamate $(9 \mu \mathrm{M})>t$-ACPD $(50 \mu \mathrm{M})]$. In addition to being the agonist with highest affinity, quisqualate was unusual in having a more shallow concentration-response relationship (slope factor of 0.7 ) when compared to the other agonists (slope factors ranging from 1.1 to 1.3 ); this same difference can be seen in the concentration-response curves for the cloned metabotropic receptor (Masu et al., 1991). Interpretation of the dose-response data is not straightforward; the coupling of receptor to channel is certainly indirect for activation of the Xenopus oocyte Caactivated $\mathrm{Cl}$ channel and involves at least a $\mathrm{G}$-protein in the casc of hippocampal Ca channels (Fig. 12). The comparison, however, leaves little doubt that a metabotropic glutamate receptor mediates the effect of L-glutamate in our experiments.

Although $1 S, 3 R$-ACPD is the least potent of the agonists $\left(\mathrm{EC}_{50}\right.$ $=15 \mu \mathrm{M})$, in many ways it is the most useful because it has the best selectivity for activating the metabotropic receptor without affecting the glutamate receptors that directly activate cation channels (Palmer et al., 1988; Manzoni et al., 1990; Miller, 1991). The ability of $1 S, 3 R$-ACPD to inhibit Ca channels in hippocampal neurons has also been reported by Sahara and Westbrook (1991), who found partial antagonism by L-AP3; we did not observe noncompetitive antagonism by L-AP3, but our results do not rule out a weak competitive antagonism.

Our results are different than those of Chernevskaya et al. (1991), who reported a slowly developing, irreversible depression of $\mathrm{Ca}$ current by L-glutamate that could be mimicked by NMDA and L-aspartate, but not quisqualate. Although we saw no effect of NMDA receptor agonists, we focused on rapid, reversible effects of L-glutamate and its structural analogs. We typically applied agonists for about $10 \mathrm{sec}$, which may not be long enough to see the effect reported by Chernevskaya et al. (1991). Comparing the two sets of results leaves open the possibility that there are two pathways by which glutamate can depress $\mathrm{Ca}$ current in hippocampal neurons, produced by different receptor types.

\section{Ca channel type}

Norepinephrine, luteinizing hormone-releasing hormone, and neuropeptide Y modulate $\omega$-CgTx-GVIA-sensitive (N-type) but not dihydropyridine-sensitive (L-type) channels in sympathetic neurons (Plummer et al., 1991; Boland and Bean, in press). Similar results were found for norepinephrine and GABA in chick dorsal root ganglion neurons (Cox and Dunlap, 1992). In dorsal raphe neurons, 5-HT also modulates $\omega$-CgTx-GVIA-sensitive channels (Penington et al., 1991). In CA3 pyramidal neurons, the metabotropic glutamate receptor agonist $1 S, 3 R-A C P D$ had no effect on dihydropyridine-sensitive channels (see Figs. $8-10$ ). About two-thirds of the current modulated by $1 S, 3 R$ ACPD was sensitive to $\omega$-CgTx-GVIA (Fig. 11), while the remainder was neither $\omega$-CgTx-GVIA sensitive nor dihydropyridine sensitive.

\section{Coupling of receptor to Ca channels}

The speed and reversibility of the L-glutamate effect we have seen are similar to those of other transmitters that have been found to inhibit Ca channels. In fact, the effects of metabotropic glutamate receptor agonists are quite similar to those of $\mathrm{ACh}$, 2-Cl-adenosine, and baclofen (Toselli and Lux, 1989; Scholz and Miller, 1991a,b; K. J. Swartz and B. P. Bean, unpublished observations; Fig. 13) on hippocampal neurons. After inhibition by L-glutamate, the current sometimes showed a slow phase of activation (e.g., Fig. $2 A$ ) that is typical of a number of other transmitters working through $\mathrm{G}$-protein-linked receptors (Forscher and Oxford, 1985; Marchetti et al., 1986; Ikeda and Schofield, 1989; Kasai and Aosaki, 1989; Carbone and Swandulla, 1991; Penington et al., 1991). In the presence of internal GTP- $\gamma-S$, the Ca channel current suppression by $1 S, 3 R-A C P D$ was irreversible and could be elicited only once, further suggesting the involvement of a G-protein in the coupling process.

The best-studied action of metabotropic glutamate receptors is the stimulation of phospholipase $C$ and the subsequent actions of inositol phospholipids on intracellular Ca stores (Sladeczek et al., 1988; Schoepp et al., 1990b; Miller, 1991). It is unlikely that release of intracellular Ca stores is the message that links receptors to $\mathrm{Ca}$ channels in our experiments. $\mathrm{Ba}$ was used as the charge carrier, and intracellular $\mathrm{Ca}$ levels were buffered by 9 mM EGTA. In Xenopus oocytes, millimolar concentrations of EGTA abolish Ca-activated chloride currents brought about by activation of metabotropic glutamate receptors and subse- 
quent release of $\mathrm{Ca}$ from intracellular stores (Manzoni et al., 1990; Masu et al., 1991). Furthermore, the suppression of Ca channel current by metabotropic glutamate receptor agonists was initiated and terminated rapidly, and could be elicited repeatedly with no diminution in response (e.g., Fig. $7 B$ ).

Our studies with cell-free outside-out patches and cell-attached patches suggest that the coupling between metabotropic glutamate receptors, G-proteins, and Ca channels is physically restricted and does not involve readily diffusible second messengers. While not directly tested in the present studies, a direct action of G-proteins on Ca channels (Yatani et al., 1987; Imoto et al., 1988), would be consistent with our results.

The fast and reversible inhibition we have studied is in contrast to the slower effects of glutamate in cultured hippocampal neurons previously reported by Iester and Jahr (1990), which had a requirement for internal or external $\mathrm{Ca}$. Metabotropic glutamate receptor agonists have also been found to inhibit highthreshold Ca current in cortical neurons (Sayer et al., 1992); in contrast to our results, inhibition in cortical neurons required 2-5 min to reach completion and was selective for L-type $\mathrm{Ca}$ channels. We would not have detected such slow effects with the brief applications $(\sim 10 \mathrm{sec})$ we used in most experiments (although we did apply $1 S, 3 R$-ACPD for several minutes in making recordings from cell-attached patches, where we also saw no inhibition of L-type channels). Taking the results from different preparations together, it is possible that two pathways exist that couple metabotropic glutamate receptors to $\mathrm{Ca}$ channels, one that is fast and membrane delimited and acts primarily on N-type Ca channels, and another that is slow and acts primarily on L-type Ca channels. Such a scenario would be similar to the modulation of Ca channels in rat sympathetic neurons by muscarinic agonists, where distinct fast and slow pathways exist with differing selectivities for Ca channel types (Beech et al. 1991; Bernheim et al., 1991a,b).

\section{Physiological significance}

Our results show that a metabotropic glutamate receptor can modulate $\omega-\mathrm{CgTx}$-GVIA-sensitive $\mathrm{Ca}$ channels in CA3 pyramidal neurons through a physically restricted mechanism involving G-proteins. Synaptic transmission in rat hippocampus involves activation of $\omega$-CgTx-GVIA-sensitive Ca channels (Kamiya et al., 1988). If metabotropic receptor modulation of Ca channels is operational at the presynaptic terminal, its activation would be expected to produce an inhibition of excitatory synaptic transmission. Concentrations of $t$-ACPD like those effective in inhibiting Ca channels have been found to suppress excitatory transmission at CA3-CAl synapses (Baskys and Malenka, 1991) and at cortical-striatal synapses (Lovinger, 1991), suggesting that modulation of Ca channels by metabotropic glutamate receptors may be physiologically important for regulating the release of L-glutamate from excitatory synapses.

\section{References}

Anwyl R (1991) Modulation of vertebrate neuronal calcium channels by transmitters. Brain Res Rev 16:265-281.

Aosaki T, Kasai H (1989) Characterization of two kinds of highvoltage-activated Ca channel currents in chick sensory neurons. Differential sensitivity to dihydropyridines and omega-conotoxin GVIA. Pfluegers Arch 414:150-156.

Baskys A, Malenka RC (1991) Agonists at metabotropic glutamate receptors presynaptically inhibit EPSCs in neonatal rat hippocampus. J Physiol (Lond) 444:687-701.

Beech DJ, Bernheim L, Mathie A, Hille B (1991) Intracellular Ca buffers disrupt muscarinic suppression of Ca current and $\mathbf{M}$ current in rat sympathetic neurons. Proc Natl Acad Sci USA 88:652-656.

Bernheim L, Beech DJ, Hille B (1991a) A diffusible second messenger mediates one of the pathways coupling receptors to calcium channels in rat sympathetic neurons. Neuron 6:859-867.

Bernheim L, Mathie A, Hille B (1991b) Muscarinic modulation of Nand L-calcium channels in rat sympathetic neurons. Soc Neurosci Abstr 17:61.

Boland L, Bean BP (in press) Modulation of N-type calcium channels in bullfrog sympathetic neurons by luteinizing hormone-releasing hormone: kinetics and voltage dependence. $J$ Neurosci, in press.

Carbone E, Swandulla D (1991) Do calcium channel classifications account for neuronal calcium channel diversity? Trends Neurosci 14: 46-51.

Chernevskaya NI, Obukhov AG, Krishtal OA (1991) NMDA receptor agonists selectively block N-type calcium channels in hippocampal neurons. Nature 349:418-420.

Cox DH, Dunlap K (1992) Pharmacological discrimination of N-type from L-type calcium current and its selective modulation by transmitters. J Neurosci 12:906-914.

Dingledine R, Boland LM, Chamberlin NL, Kawasaki K, Kleckner NW, Traynelis SF, Verdoorn TA (1988) Amino acid receptors and uptake systems in the mammalian central nervous system. CRC Crit Rev Neurobiol 4:1-96.

Fisher R, Johnston D (1990) Differential modulation of single voltagegated calcium channels by cholinergic and adrenergic agonists in adult hippocampal neurons. J Neurophysiol 64:1291-1302.

Fisher RE, Gray R, Johnston D (1990) Properties and distribution of single voltage-gated calcium channels in adult hippocampal neurons. J Neurophysiol 64:91-103.

Forscher P, Oxford FS (1985) Modulation of calcium channels by norepinephrine in internally dialyzed avian sensory neurons. J Gen Physiol 85:743-763.

Friel DD, Bean BP (1988) Two ATP-activated conductances in bullfrog atrial cells. J Gen Physiol 91:1-27.

Furshpan EJ, Potter DD (1989) Seizure-like activity and cellular damage in rat hippocampal neurons in cell culture. Neuron 3:199-207.

Gross RA, MacDonald RL, Ryan-Jastrow T (1989) 2-Chloroadenosine reduces the $\mathbf{N}$ channel current of cultured mouse sensory neurones in a pertussis toxin-sensitive manner. J Physiol (Lond) 411: 585-595.

Hamill OP, Marty A, Neher E, Sakmann B, Sigworth FJ (1981) Improved patch-clamp techniques for high-resolution current recording from cells and cell-free membrane patches. Pfluegers Arch 391:85100.

Holz GG, Rane SG, Dunlap K (1986) GTP-binding proteins mediate transmitter inhibition of voltage-dependent calcium channels. Nature 319:670-672.

Honore T, Davies SN, Drejer J, Fletcher EJ, Jacobsen P, Lodge D, Nielsen FE (1988) Quinoxalinediones: potent competitive nonNMDA glutamate receptor antagonists. Science 241:701-703.

Houamed KM, Kuijper JL, Gilbert TL, Haldeman BA, O’Hara PJ, Mulvihill ER, Almers W, Hagen FS (1991) Cloning, expression, and gene structure of a $\mathrm{G}$ protein-coupled glutamate receptor from rat brain. Science 252:1318-1321.

Ikeda SR, Schofield G (1989) Somatostatin blocks a calcium current in rat sympathetic ganglion neurones. J Physiol (Lond) 409:221-240.

Illes P (1986) Mechanisms of receptor-mediated modulation of transmitter release in noradrenergic, cholinergic and sensory neurons. Neuroscience 17:909-928.

Imoto Y, Yatani A, Reeves JP, Codina J, Birnbaumer L, Brown AM (1988) $\alpha$-Subunit of $G_{s}$ directly activates cardiac calcium channels in lipid bilayers. Am J Physiol 255:H722-H728.

Irving AJ, Schofield G, Watkins JC, Sunter DC, Collingridge GL (1990) $1 S, 3 R$-ACPD stimulates and L-AP3 blocks $\mathrm{Ca}$ mobilization in rat cerebellar neurons. Eur J Pharmacol 186:363-365.

Johnson JW, Ascher P (1987) Glycine potentiates the NMDA response in cultured mouse brain neurons. Nature 325:529-531.

Kalsner S, Westfall TC, eds (1990) Annals of the New York Academy of Science, Vol 604, Presynaptic receptors and the question of au- 
toregulation of neurotransmitter release. New York: New York Academy of Science.

Kamiya H, Sawada S, Yamamoto C (1988) Synthetic omega-conotoxin blocks synaptic transmission in the hippocampus in vitro. Neurosci Lett 91:84-88.

Kasai H, Aosaki T (1989) Modulation of Ca-channel current by an adenosine analog mediated by a GTP-binding protein in chick sensory neurons. Pfluegers Arch 414:145-149.

Kiskin NI, Krishtal OA, Tsyndrenko AY (1986) Excitatory amino acid receptors in hippocampal neurons: kainate fails to desensitize them. Neurosci Lett 63:225-230.

Kiskin NI, Krishtal OA, Tsyndrenko AY (1990) Cross-desensitization reveals pharmacological specificity of excitatory amino acid receptors in isolated hippocampal neurons. Eur J Neurosci 2:461 -470 .

Kleckner NW, Dingledine R (1988) Requirement for glycine in activation of NMDA-receptors expressed in Xenopus oocytes. Science 241:835-837.

Kleuss C, Hescheler J, Ewel C, Rosenthal W, Schultz G, Wittig B (1991) Assignment of a G-protein subtypes to specific receptors inducing inhibition of calcium currents. Nature 353:43-48.

Koelle GB (1961) A proposed dual neurohumoral role of acetylcholine: its functions at the pre- and post-synaptic sites. Nature 190:208-211.

Lester RA, Jahr CE (1990) Quisqualate receptor-mediated depression of calcium currents in hippocampal neurons. Neuron 4:741-749.

Lewis DL, Weight FF, Luini A (1986) A guanine nucleotide-binding protein mediates the inhibition of voltage-dependent calcium current by somatostatin in a pituitary cell line. Proc Natl Acad Sci USA 83: 9035-9039.

Lipscombe D, Kongsamut S, Tsien RW (1989) $\alpha$-Adrenergic inhibition of sympathetic neurotransmitter release mediated by modulation of N-type calcium-channel gating. Nature 340:639-642.

Lovinger DM (1991) Trans-1-aminocyclopentane-1,3-dicarboxylic acid $(t$-ACPD) decreases synaptic excitation in rat striatal slices through a presynaptic action. Neurosci Lett 129:17-21.

Maguire G, Maple B, Lukasiewicz P, Werblin F (1989) $\gamma$-Aminobutyrate type $B$ receptor modulation of L-type calcium channel current at bipolar cell terminals in the retina of the tiger salamander. Proc Natl Acad Sci USA 86:10144-10147.

Manzoni O, Fagni L, Pin J, Rassendren F, Poulat F, Sladeczek F, Bockaert J (1990) (trans)-1-amino-cyclopentyl-1,3-dicarboxylate stimulated quisqualate phosphoinositide-coupled receptors but not ionotropic glutamate receptors in striatal neurons and Xenopus oocytes. Mol Pharmacol 38:1-6.

Marchetti C, Carbone E, Lux HD (1986) Effects of dopaminc and noradrenaline on $\mathrm{Ca}$ channels of cultured sensory and sympathetic neurons of chick. Pfluegers Arch 406:104-111.

Masu M, Tanabe Y, Tsuchida K, Shigemoto R, Nakanishi S (1991) Sequence and expression of a metabotropic glutamate receptor. $\mathrm{Na}$ ture 349:760-765.

Mayer ML, Westbrook GL (1987) The physiology of excitatory amino acids in the vertebrate central nervous system. Prog Neurobiol 28: $197-276$

Miller RJ (1991) Metabotropic excitatory amino acid receptors reveal their true colors. Trends Pharmacol Sci 12:365-367.

Mintz IM, Adams ME, Bean BP (1992) P-Type Ca channels in rat central and peripheral neurons. Neuron 9:1-20.

Mogul DJ, Fox AP (1991) Evidence for multiple types of Ca channels in acutcly isolated hippocampal CA3 neurones of the guinca-pig. $\mathrm{J}$ Physiol (Lond) 433:259-281.

Nicoletti F, Meek JL, Iadorola MJ, Chuang DM, Roth BL, Costa E (1986a) Coupling of inositol phospholipid metabolism with excitatory amino acid recognition sites in rat hippocampus. J Neurochem 46:40-46.

Nicoletti F, Iadorola MJ, Wroblewski JT, Costa E (1986b) Excitatory amino acid recognition sites coupled with inositol phospholipid metabolism: developmental changes and interactions with alpha $a_{1}$-adrenoceptors. Proc Natl Acad Sci USA 83:1931-1935.

North RA (1986) Receptors on individual neurones. Neuroscience 17: 899-907.

Nowycky MC, Fox AP, Tsien RW (1985) Long-opening mode of gating of neuronal calcium channels and its promotion by the dihydropyridinc calcium agonist Bay K 8644. Proc Natl Acad Sci USA 82:21782182 .
O'Brien RJ, Fischbach GD (1986) Characterization of excitatory amino acid receptors expressed by embryonic chick motor neurons in vitro. J Neurosci 6:3275-3283.

O'Dell TJ, Alger BE (1991) Single calcium channels in rat and guineapig hippocampal neurons. J Physiol (Lond) 436:739-767.

Palmer E, Monaghan DT, Cotman CW (1989) trans-ACPD, a selective agonist of the phosphoinositide-coupled excitatory amino acid receptor. Eur J Pharmacol 166:585-587.

Patneau DK, Mayer ML (1990) Structure-activity relationships for amino acid transmitter candidates acting at $N$-methyl-D-aspartate and quisqualate receptors. J Neurosci 10:2385-2399.

Patneau DK, Mayer ML (1991) Kinetic analysis of interactions between kainate and AMPA: evidence for activation of a single receptor in mouse hippocampal neurons. Neuron 6:785-798.

Penington NJ, Kelly JS, Fox AP (1991) A study of the mechanism of Ca current inhibition produced by serotonin in rat dorsal raphe neurons. J Neurosci 11:3594-3609.

Plummer MR, Logothetis DE, Hess P (1989) Elementary properties and pharmacological sensitivities of calcium channels in mammalian peripheral neurons. Neuron 2:1453-1463.

Plummer MR, Rittenhouse A, Kanevsky M, Hess P (1991) Neurotransmitter modulation of calcium channels in rat sympathetic neurons. J Neurosci 1 1:2339-2348.

Regan LJ, Sah DWY, Bean BP (1991) Ca channels in rat central and peripheral neurons: high-threshold current resistant to dihydropyridine blockers and $\omega$-conotoxin. Neuron 6:269-280.

Reuter H (1983) Calcium channel modulation by neurotransmitters, enzymes and drugs. Nature 301:569-574.

Sah DW (1990) Neurotransmitter modulation of calcium current in rat spinal cord neurons. J Neurosci 10:136-141.

Sahara Y, Westbrook GL (1991) trans-ACPD blocks high-threshold calcium currents on cultured hippocampal neurons. Soc Neurosci Abstr 17:1168.

Sayer RJ, Schwindt PC, Crill WE (1992) Metabotropic glutamate receptor-mediated suppression of L-type Ca current in acutely isolated neocortical neurons. $J$ Neurophysiol, in press.

Schoepp DD, Johnson BG (1988) Excitatory amino acid agonist-antagonist interactions at 2-amino-4-phosphonobutyric acid-sensitive quisqualate receptors coupled to phosphoinositide hydrolysis in slices of rat hippocampus. J Neurochem 50:1605-1613.

Schoepp DD, Johnson BG (1989) Comparison of excitatory amino acid-stimulated phosphoinositide hydrolysis and $N$ - $\left[{ }^{3} \mathrm{H}\right]$-acetylaspartylglutamate binding in rat brain: selective inhibition of phosphoinositide hydrolysis by 2-amino-3-phosphonoproprionate. J Neurochem 53:273-278.

Schoepp DD, Johnson BG, Smith ECR, McQuaid LA (1990a) Stereoselective and mode of inhibition of phosphoinositide-coupled excitatory amino acid receptors by 2-amino-3-phosphonopropionic acid. Mol Pharmacol 38:222-228.

Schoepp DD, Bockaert J, Sladeczek F (1990b) Pharmacological and functional characteristics of metabotropic excitatory amino acid receptors. Trends Pharmacol Sci 11:508-515.

Scholz KP, Miller RJ (1991a) Analysis of adenosine actions on $\mathrm{Ca}^{2+}$ currents and synaptic transmission in cultured rat hippocampal pyramidal neurones. J Physiol (Lond) 435:373-393.

Scholz KP, Miller RJ (1991b) GABA $_{B}$ receptor-mediated inhibition of $\mathrm{Ca}$ currents and synaptic transmission in cultured rat hippocampal neurones. J Physiol (Lond) 444:669-686.

Sladeczek F, Pin J, Recasens M, Bockaert J, Weiss S (1985) Glutamate stimulates inositol phosphate formation in striatal ncurons. Nature 317:717-719.

Sladeczek F, Recasens M, Bockaert J (1988) A new mechanism for glutamate receptor action: phosphoinositide hydrolysis. Trends Neurosci 11:545-549.

Starke K (1987) Presynaptic $\alpha$-autoreceptors. Rev Physiol Biochem Pharmacol 107:73-146.

Sugiyama H, Ito I, Hirono C (1987) A new type of glutamate receptor linked to inositol phospholipid metabolism. Nature 325:531-533.

Sugiyama H, Ito I, Watanabe M (1989) Glutamate receptor subtypes may be classified into two major categories: a study on Xenopus oocytes injected with rat brain mRNA. Neuron 3:129-132.

Takahashi K, Wakamori M, Akaike N (1989) Hippocampal CAI 
pyramidal cells of rats have four voltage-dependent calcium conductances. Neurosci Lett 104:229-234.

Thompson SM, Wong RKS (1991) Development of calcium current subtypes in isolated rat hippocampal pyramidal neurons. J Physiol (Lond) 439:671-689.

Toselli M, Lux HD (1989) GTP-binding proteins mediate acetylcholine inhibition of voltage dependent calcium channels in hippocampal neurons. Pfluegers Arch 413:319-321.

Toselli M, Taglietti V (1990) Pharmacological characterization of voltage-dependent calcium currents in rat hippocampal neurons. Neurosci Lett 112:70-75.

Ui M (1984) Islet-activating protein, pertussis toxin: a probe for functions of the inhibitory guanine nucleotide regulatory component of adenylate cyclase. Trends Pharmacol Sci 5:277-279.
Verdoorn TA, Dingledine R (1988) Excitatory amino acid receptors expressed in Xenopus oocyte: agonist pharmacology. Mol Pharmacol 34:298-307.

Verdoorn TA, Kleckner NW, Dingledine R (1989) $N$-methyl-D-aspartate/glycine and quisqualate/kainate receptors expressed in Xenopus oocytes: antagonist pharmacology. Mol Pharmacol 35:360-368.

Yatani A, Codina J, Imoto Y, Reeves JP, Birnbaumer L, Brown AM (1987) A G protein directly regulates mammalian cardiac calcium channels. Science 238:1288-1292.

Zorumski CF, Yang J (1988) AMPA, kainate and quisqualate activate a common receptor-channel complex on embryonic chick motor neurons. J Neurosci 8:4277-4286. 